This is an Accepted Manuscript of an article published in Global Crime on 21 February

2014, available online: http://www.tandfonline.com/ 10.1080/17440572.2014.882777

\title{
A new method for estimating the illicit cigarette market at the subnational level and its application to Italy
}

\author{
Francesco Calderoni
}

Università Cattolica del Sacro Cuore and Transcrime, Milan, Italy

\begin{abstract}
This study provides a methodology with which to estimate the volumes and revenues of the illicit cigarette market at the subnational level. It applies the methodology to Italy for a four-year period (2009-2012), enabling assessment of the prevalence of the illicit trade across years and regions. Notwithstanding the alleged importance of mafias, the results provide a more complex picture of the Italian illicit tobacco market. The maximum total revenues from the ITTP increased from $€ 0.5 \mathrm{bn}$ in 2009 to $€ 1.2 \mathrm{bn}$ in 2012 . The prevalence of illicit cigarettes varies significantly across regions, due to the proximity to countries with cheaper cigarettes and the possible occurrence of other crime opportunities. Understanding of these factors is crucial for the development of appropriate policies against the ITTP. The methodology provided may be applicable to all other EU countries, providing detailed, yearly estimates of the illicit market at the subnational level.
\end{abstract}

Keywords: illicit trade in tobacco products; cigarette smuggling; counterfeiting; illicit whites; mafias; criminal markets; estimating criminal revenues.

\section{Introduction}

The illicit trade in tobacco products (hereinafter ITTP) comprises a variety of illegal activities, extending beyond the most popular categories of smuggling and counterfeiting. The most common definition of the ITTP (Article 1 of the Framework Convention on Tobacco Control of the World Health Organization), is broad and 
somewhat tautological. ${ }^{1}$ In fact, the ITTP encompasses different conducts, from criminal offences to administrative violations: namely, contraband (transport or sale of tobacco products from a country without paying taxes or violating laws that control the import and the export); counterfeiting (illegal production of goods with a trademark or a copy of the latter without the owners' permission); "cheap whites" or "illicit whites" (cigarettes produced in one country in order to be illegally exported to another country where the same products are not distributed in the legal market); "unbranded" tobacco (hand-rolled or semi-finished tobacco, or also loose tobacco leaves with no labelling or health warning); bootlegging (the purchase of legal tobacco in low-tax countries for illegal resale in countries with higher taxes); and illegal production (products not declared to the tax authorities). ${ }^{2}$ These different activities are inherently associated with the fact that tobacco products are legal commodities available in a market context.

The tobacco market is a dual market with a legal and illegal side. ${ }^{3}$ The interaction between the two sides is due to numerous socio-economic, cultural and normative factors, including activities to combat trafficking. ${ }^{4}$ In the legal market, tobacco products are subject to strict regulation and high taxation due to their serious consequences for human health. Despite intensive regulation, the tobacco market is a truly global one, with multinational companies, centralized manufacturing (driven by economies of scale and the relatively easy transport of the products), and important import-export dynamics. The functioning of the legal tobacco market inevitably affects the illicit trade as well.

For the above-mentioned reasons, the ITTP is a problem in various respects. It affects tobacco control policies, supplying cheap and often uncontrolled tobacco products and jeopardizing efforts to reduce smoking; it deprives governments of 
revenues from taxation; it impacts on the economy by unfairly competing with the sectors of tobacco manufacturing, wholesale and retail distribution. ${ }^{5}$

This study provides a methodology for the production of subnational (nuts- $2^{6}$ level) estimates of the volumes and revenues of the ITTP and particularly of illicit cigarettes. ${ }^{7}$ It applies the estimation methodology to Italy, which is an interesting case study because of the traditional role of tobacco smuggling for the Italian mafias and the evolution of the ITTP in recent decades. The estimates for Italy show that the increase of the illicit market in the last four years is due to a generalized growth across all regions between 2009 and 2011. In 2012, the increase was mostly driven by three regions. Calculation of the revenues at the retail level from the ITTP point out that the allegation that the Italian mafias are earning up to $€ 0.9$ bn is unfounded.

The rest of the article is organized as follows: the first section briefly reviews the characteristics of the illicit trade in tobacco products and the existing estimates. The second section focuses on Italy, analyzing the evolution of the ITTP in the past years and presenting qualitative and quantitative information available today. The third section outlines the methodology used for this study as well as its limitations, while the fourth section presents and discusses the results. The last section concludes the article.

\section{The illicit trade in tobacco products: characteristics and estimates}

\section{Demand and supply}

The demand for illicit tobacco products is associated with several factors. In particular, several studies have shown that the main factor determining the consumption of illicit tobacco is the price, which is significantly lower than that of the legitimate products. The price of illicit products may vary by country, product, and other conditions of sale, and it ranges from $25 \%$ to $90 \%$ less than that of legitimate products. ${ }^{8}$ 
In addition to price differentials, the literature has shown that smokers in low socioeconomic conditions are more likely to consume illicit tobacco. ${ }^{9}$ Furthermore, in some countries and areas where smuggling is a common practice, the consumption of illicit cigarettes may be regarded as a socially acceptable practice. $^{10}$

Also the supply of illicit tobacco is strongly influenced by the dynamics of prices and taxes. Cigarettes are in fact the commodity with the highest tax value by weight, and the retail price is mainly determined by taxes, which may even exceed 70$80 \%$ of the same. ${ }^{11}$ The illicit market aims to minimize or avoid taxes paid on products, and this makes it a business that can generate high profits. ${ }^{12}$ Other factors favoring the development of the illicit tobacco market include: the availability of cheap (including illegal) tobacco products, with areas close to cheaper cigarettes being more vulnerable to various forms of tax avoidance (both licit and illicit) ${ }^{13}$ the dynamics and regulation of the legal market, e.g. the transit trade regime allowing the suspension of taxation for exported/imported commodities transiting through third countries; ${ }^{14}$ illicit practices by some manufacturers, e.g. the supply of quantities of cigarettes exceeding the domestic demand to some countries from where the products are subsequently smuggled exploiting corruption and international trade schemes $;{ }^{15}$ and the adoption of effective prevention policies and criminal enforcement actions. ${ }^{16}$ Although a high level of taxation may be the initial incentive for the supply of illicit tobacco, these other factors are crucial for the development and maintenance of the illicit trade.

\section{The actors of the ITTP}

The literature has shown the presence of a variety of actors involved in the illicit tobacco market. First, the tobacco industry has been repeatedly reported for contributing to the smuggling of tobacco products. In many countries, governments have taken legal 
action for the fiscal losses caused by the industry's exploitation of transit trade resulting in significant smuggling of tobacco products. ${ }^{17}$ The pressure on the industry has led manufacturers to implement better controls on the supply chain and on the destination countries. ${ }^{18}$ Another result was the signature of cooperation agreements with the authorities of various countries. ${ }^{19}$ The agreements have improved the prevention and fight against large-scale tobacco smuggling, introducing systems to track and trace tobacco products and imposing payment on manufacturers in case the authorities seize products which are not counterfeit. ${ }^{20}$

Second, much of the criminological literature reports that those involved in the illicit tobacco trade are mainly small groups or independent criminal entrepreneurs. ${ }^{21}$ These studies, primarily in the Netherlands, Germany, Greece and the United Kingdom, maintain that large organizations, structured and stable over time, should be considered exceptional in the illicit tobacco market. Even in the presence of quite extensive and organized criminal networks, as in the case of groups of Vietnamese origin in Berlin, there were no elements that suggested the creation of large coalitions or groups with an elaborate structure able to achieve monopoly on the illicit market by, for example, the frequent use of violence. ${ }^{22}$

Finally, several sources report the involvement of organized crime and terrorist groups in the illicit tobacco trade. These groups are attracted by the possibility of high profits with a low risk of identification and conviction. They take advantage of the international exchange networks already used, for example, to traffic drugs, arms and human beings. ${ }^{23}$ According to various sources, stable and organized criminal groups, such as the Italian mafias, Eastern European or Asian criminal organizations are present in different phases of the trade. These groups participate in the smuggling, ${ }^{24}$ forgery, ${ }^{25}$ storing and processing of illicit tobacco. ${ }^{26}$ In regard to terrorist organizations, some 
studies have argued for their involvement in illicit tobacco. ${ }^{27}$ However, these analyses are based on a limited number of cases and are often conducted on heterogeneous sources, such as official reports and articles in the media, which may over-emphasize the role of criminal and terrorist organizations. Some scholars have therefore argued that the involvement of terrorists and mafias is rare, and that in any case they are unable to monopolize such a large illicit market. ${ }^{28}$

\section{Estimates of the ITTP}

Several studies have estimated the size of the illicit tobacco market at the global, continental and national level. The availability of studies is probably due to the impact that illicit trade can have on legitimate manufacturers and tobacco control policies, and to the importance that taxes on tobacco products have for governments. This promotes estimations of the size and the fiscal impact of the illicit market to monitor and facilitate action against it. However, the agendas of the estimators may have an influence on the estimation process: manufacturers may prefer high figures to get more attention by the law enforcement agencies, policymakers may want to minimize the issue as this may indicate problems of efficiency or corruption, and tobacco control activist may either prefer higher, e.g. to point out the manufacturers' role in the ITTP, or lower numbers, e.g. to minimize the unwanted effects of tobacco control measures. ${ }^{29}$

Despite the abundance of estimations, there is no general consensus on the methodology. Existing studies are often based on various sources collected at irregular intervals. In particular, the approaches used have focused, for example, on the difference between exports and imports declared, or official/expert estimates, the link between sales and official prices in neighboring countries, consumer surveys, and observational data collection (inspection of packs and other products) ${ }^{30}$ In addition to 
the above mentioned biases due to the estimators' agendas, each of these methods has limitations with regard to the inclusion of various forms of trafficking and its reliability in the estimate.

At the global level, different studies have estimated the world illicit market at around $6 \%$ of total consumption in $1993,8.5 \%$ in $1995,10.7 \%$ in 2006 , and $11.6 \%$ in 2007. ${ }^{31}$ Although these estimates provide quite similar (and growing) values, they result from different approaches and different data of limited reliability. The only source providing yearly estimates of the illicit trade in tobacco products for a large number of countries (currently 80), is Euromonitor International (hereinafter EMI). EMI is a private company which publishes periodic reports on the global (and regional) illicit tobacco markets, estimating their size, revenues and related tax losses. ${ }^{32}$ For 2011, EMI estimated illicit cigarettes at 571.8 billion units, corresponding to $9 \%$ of the world market (a figure that rises to $11.5 \%$ when excluding the main national market, China). ${ }^{33}$ However, EMI does not provide detailed information on the methodology used, and several studies have challenged the reliability of its estimates. ${ }^{34}$

At the level of the European Union, Joossens and colleagues stated that the illicit market share was about 58 billion cigarettes in 2007 (8.5\% of the total market). ${ }^{35}$ Furthermore, a 2010 consumer survey on 17 EU countries and Albania reported that $3.4 \%$ of consumers purchased cigarettes "from an individual selling cigarettes independently at local markets, delivery service, door-to-door, or just in the street", while $8.4 \%$ of smokers purchased from the same channels at least $1 \%$ of their consumption in the previous 30 days. ${ }^{36}$ However, the authors acknowledged that the results may underestimate the size of the illicit market due to underreporting. To address this issue, the study also calculated a "tax evasion score" based on the characteristics of the cigarette packs shown by the consumers surveyed. ${ }^{37}$ The tax 
evasion score across all the countries was $8.1 \% .^{38}$ The difference between the prevalence of smuggling reported by consumers and the tax evasion score further confirms the limited reliability of surveys for the measurement of the illicit trade. EMI provides national estimates of the ITTP for 25 out of 28 EU Member States, since there are no estimates for Luxembourg, Cyprus and Malta. The estimates of the illicit market, still with no detail on the methodology used to calculate them, amounted to $67.3 \mathrm{bn}$ cigarettes in 2007 (8.8\% of total consumption) and 77.3 bn in 2012 (12.2\% of total consumption). ${ }^{39}$

Project Star provides a further estimate at the EU level. Since 2006, the project has provided annual estimates of the illicit tobacco market at a national and EU level, both in volume and as a percentage of the total market. Project Star is conducted by KPMG in furtherance of the agreements concluded among Philip Morris International, the European Commission, OLAF and the Member States to tackle the illicit trade. ${ }^{40}$ The project is based on data on legal sales, consumer surveys and empty packs surveys (EPSs). ${ }^{41}$ EPSs are contracted out by the main tobacco manufacturers to different market analysis companies. In each country, they periodically collect a sample of littered cigarette packs in a number of medium and large cities. The surveys aim to assess the market shares of manufacturers and brands, and to measure the prevalence of non-domestic and counterfeit products. To this purpose, each pack is analyzed to identify the manufacturer, brand, country variant and whether it is a counterfeit. According to the last issue of Project Star, in 2012 the ITTP amounted to $65.5 \mathrm{bn}$ cigarettes, i.e. $11.1 \%$ of total consumption.

Some studies challenged the reliability of Project Star. ${ }^{42}$ Joossens and colleagues questioned the results, arguing that "the methodology for the collection of the empty packs in the report is insufficiently explained to judge its validity and that the report 
relies heavily on expertise and data provided by the tobacco industry". ${ }^{43}$ A study reviewing the methodology of Project Star argued that the study may "provide a useful contribution to the debate", since "its strength lies in the production of a useful model and providing estimates [...] independent of seizure data on which, despite their bias, such estimates are usually based" ${ }^{44}$ However, the authors pointed out a number concerns about the methodology: lack of transparency and details on the data used in the model, overreliance on industry-produced data, risk of overestimation and the lack of external validation. ${ }^{45}$

While most of the above concerns are important, Project Star still represents the best source of yearly estimates of the prevalence of the ITTP in the EU, enabling assessment of the evolution of the ITTP since 2006 through a constant methodology. With the exception of EMI's opaque estimations, there is no other source providing annual figures for each EU country. The criticisms about the industry-supported EPSs often overlook that such sources also provide some advantages. For example, EPSs are currently conducted by independent market analysis companies for the four main manufacturers. The sample size is large (more than 10,000 packs per wave in most EU countries). Identification of counterfeits is conducted in cooperation with the manufacturers due to their expertise in the identification of the security features designed in the packs, a practice also common whenever law enforcement agencies seize large quantities of cigarettes. EPSs' purpose is also to measure market shares and this may reduce the risk of biases when they are jointly conducted for the four main manufacturers. Lastly, in addition to possible industry biases, the lack of transparency about the methodology and results may also be due to other elements. For example, the data may disclose sensitive information which both manufacturers and market research may be reluctant to share with potential competitors. This is also common in other 
industries (e.g. finance and insurance). At present, there is limited alternative to the use of industry data for the estimates, unless large-scale, independent data collection plans are enacted.

Alternative, independent estimates appear unsatisfactory and/or are not conducted on a country-wide annual basis. Consumer surveys may be inadequate in evaluating illicit behaviors due to respondents' biases. ${ }^{46}$ Independent pack collections, while providing more detail on the methodology, often rely on smaller samples. ${ }^{47}$ For example, three industry-funded waves of EPSs in Poland gathered 34,000 packs in August-September 2011, 34,000 in October-November 2011, and 17,000 packs in March-April of 2012 (the sample for the capital Warsaw was between 2800 and 5600 packs per wave). ${ }^{48}$ In September 2011, Stoklosa and Ross conducted an independent survey, collecting only 754 packs in Warsaw. ${ }^{49}$ Overall, whereas the public and academic opinion should discuss its reliability and require full transparency on the methodology, there is little doubt that Project Star will most likely remain a point of reference for the estimation of the ITTP in the EU.

\section{The past and present of the ITTP in Italy}

\section{The evolution of the illicit tobacco market in Italy}

Historically, the Italian illicit tobacco market has been characterized by some special elements which brought the ITTP to very high levels from the middle of the 1980s until the end of the 1990s. ${ }^{50}$ First, cigarette smuggling played an important role in the evolution of the Italian mafias (Camorra, Cosa Nostra and the Sacra Corona Unita). After World War II the illicit cigarette trade enabled Cosa Nostra and the Camorra to make considerable profits before the development of drug trafficking. ${ }^{51}$ Later, also the Sacra Corona Unita and criminal organizations from Puglia region became involved in 
cigarette smuggling, opening new entry points for illicit tobacco on Italy's south-eastern coasts. $^{52}$

Second, the business practices by tobacco manufacturers contributed to the illicit trade. These included, for example, the sale of products to some neighboring countries in quantities largely exceeding the domestic demand for cigarettes. ${ }^{53}$ The cigarettes were subsequently smuggled to Italy.

Third, the authorities of the neighboring countries were actively involved in the smuggling schemes. For example, Montenegro (a part of the Federal Republic of Yugoslavia since 1992 and of the State Union of Serbia and Montenegro since 2003; an independent state since 3 June 2006) was one of the traditional destinations for cigarettes to be smuggled to Italy, which gained the country the nickname of "the Tortuga of the Adriatic Sea". ${ }^{54}$ Since 1992, cigarettes were sold to broker companies based in a number of countries, and delivered to Montenegro, where they paid a low tax. Allegedly, the revenues generated by cigarette smuggling made up to sixty percent of the Montenegrin domestic product. ${ }^{55}$ The cigarettes were then smuggled to Italy with the cooperation of groups affiliated to the Sacra Corona Unita and the Camorra. ${ }^{56}$ According to the Italian law enforcement and prosecution agencies, the authorities of Montenegro participated in the smuggling scheme, including the country's leading politician, both Prime Minister and President during those years. ${ }^{57}$ Eventually, however, Italian authorities eventually dropped the charges in March 2009 due to problems of diplomatic immunity. ${ }^{58}$

Since the middle of the 1990s, Italian authorities have adopted a number of measures to tackle cigarette smuggling. New legislation increased the penalties for cigarette smuggling and large scale law enforcement operations were launched, including the 2000 Operation Primavera (Springtime) which led to the arrest of more 
than 500 individuals. ${ }^{59}$ Also, since 1991 the Italian government has increased its pressure on tobacco manufacturers, e.g. suspending the sales of a number of brands in 1991 and 1992. In 1992 and 1998, it entered into two agreements with Philip Morris, the leading manufacturer on the Italian market. ${ }^{60}$ Whereas the Antimafia Parliamentary Commission contended that these agreements were unsatisfactory, in 2001 Italy, first among EU countries, joined the lawsuit filed by the European Commission in New York against PMI, which resulted in the above mentioned 2004 agreement. ${ }^{61}$ Lastly, changes in international politics led to an end of the Montenegrin connection. In fact, according to the Italian Antimafia Parliamentary Commission, until the end of the 1990s cigarette smuggling from Montenegro was tolerated for realpolitik reasons. Since 1996, Montenegrin authorities were opposing Slobodan Milosevic (President of Serbia until 1997, then President of the Federal Republic of Yugoslavia until 2000) in the period before the Kosovo War (February 1998- June 1999). After the war and the resignation of Milosevic in 2000, international support stopped, as demonstrated by the drop in the number of cases shipped to Montenegro (from 967,513 cases in 1998 to approximately 103,344 cases in 2000). ${ }^{62}$ The combined effects of these measures induced a sharp decrease in the ITTP, to the point that Italy was considered a successful case at the international level. ${ }^{63}$

\section{Information on the ITTP in Italy today}

Today, according to law enforcement agencies, various criminal organizations, both domestic and foreign, dominate the ITTP in Italy. These groups would be the only ones able to organize the complex smuggling operation in its different phases. National and foreign organized criminals, often connected with the Italian mafias, would act as

criminal enterprises, moving large quantities of cigarettes across seas and continents. ${ }^{64}$ 
The media and other sources reported that mafia proceeds from illicit tobacco would be $€ 0.9$ bn in $2010 .^{65}$

While presently available qualitative information on the ITTP highlights the important role of the mafias and organized crime, quantitative sources suggest a more complex picture. Existing estimates show that the Italian illicit tobacco market passed from high levels until the 1990s to very low ones at the beginning of the 2000s. In the most recent years, however, estimates have started to grow again (Figure 1).

Figure 1. Estimates of the illicit trade in tobacco products in Italy. Share of total consumption (1998-2012).

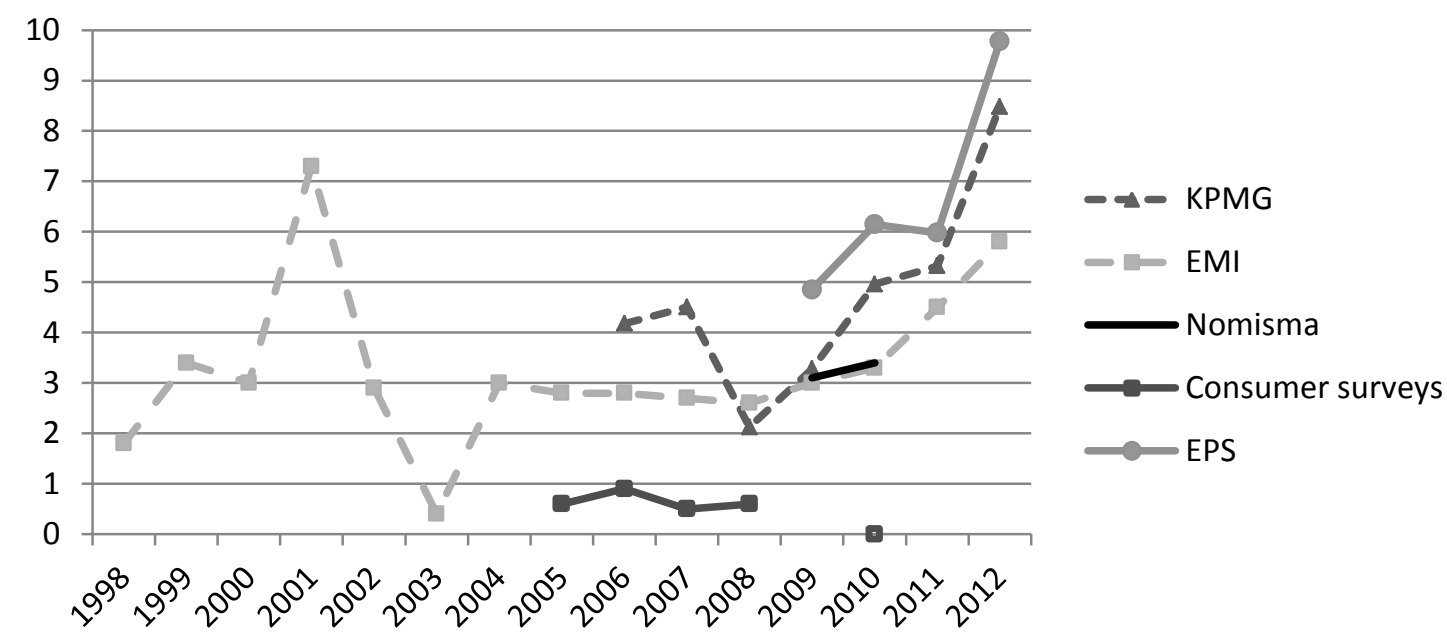

Source: author's elaboration

Several consumer surveys were conducted between 2005 and 2010. Reported purchases from illicit channels remained constantly below $1 \%$, and even $0 \%$ in $2010 .{ }^{66}$ The 2010 survey also calculated the tax evasion score based on the features of the packs shown by the surveyed sample (1.5\% of packs). ${ }^{67}$ In 2011 , Nomisma issued a report on cigarette counterfeiting in Italy. ${ }^{68}$ The report estimated the illicit tobacco market for the years 2009-2010 at about 2.8 billion cigarettes per year (3.2\% of total consumption), with 413 million $(0.5 \%)$ and 2.4 billion units $(2.7 \%)$ for counterfeits and contraband, 
respectively. The report also estimated the value of the national illegal market, which amounted to over 651 million euros, i.e. $3.6 \%$ of total market value. ${ }^{69}$ The report, however, does not provide details on the methodology used. ${ }^{70}$ Project Star assessed the illicit market share in 2012 at $8.5 \%$ of total consumption. ${ }^{71}$ In the same year, EMI estimated the penetration of illicit tobacco at $5.8 \%$ of total consumption. ${ }^{72}$

A further proxy for the illicit trade may be the prevalence of non-domestic packs in Italian empty pack surveys. Analysis of eight surveys conducted in the period 20092012 shows the national prevalence of non-domestic packs ranging from $3.7 \%$ in the second quarter of 2009 to $9.9 \%$ and $9.6 \%$ in the second and fourth quarters of 2012 , respectively (Figure 2). The use of EPSs as proxies of the illicit trade is controversial. First, they measure the prevalence of non-domestic packs, which include both legal illegal products. Further, the literature has pointed out a number of methodological uncertainties, also arguing that industry-sponsored EPSs may be biased by the industry's interest in inflating the estimates of the ITTP. ${ }^{73}$ These concerns are important and further discussion of the reliability of the Italian EPSs is provided in the methodology section.

Despite the caution due to the mentioned criticisms, EPSs are the only source assessing the illicit market penetration at the local level. This is particularly important, since the recent increase in non-domestic packs at the national level does not correspond to a general growth in all regions. Figure 2 shows different evolution patterns. While in some regions the trend of the non-domestic share was decreasing (e.g. Liguria, Calabria, Puglia) or stable (e.g. Emilia-Romagna), other regions registered a striking increase (Friuli-Venezia Giulia and Campania). The data suggest that non-domestic packs may reflect the trend in the illicit market, since tourist numbers do not have such a degree of 
variation across years and do not concentrate in the regions with the highest nondomestic prevalence. $^{74}$

Figure 2. Share of non-domestic packs out of total collected packs in empty pack surveys per region, quarter and year (2009-2012).

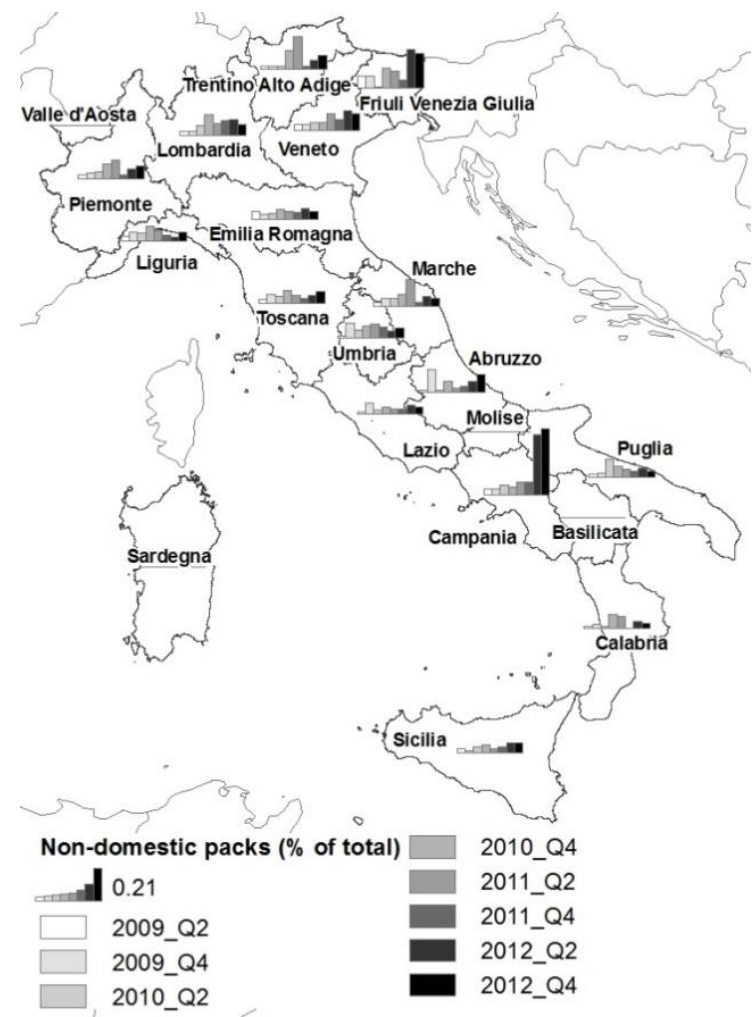

Source: author's elaboration

Finally, seizure data do not reflect the penetration of the illicit trade in tobacco products.

Data provided by the Guardia di Finanza (Italian financial police) for 2009-2012 show that seizures concentrate on land and sea borders (Figure 3). Furthermore, only a minority (between $28 \%$ and $35 \%$ ) of the seized products are destined for Italy. ${ }^{75}$ 
Figure 3. Seizures of tobacco products by the Guardia di Finanza per year and province of the seizure (grams) (2009-2012).

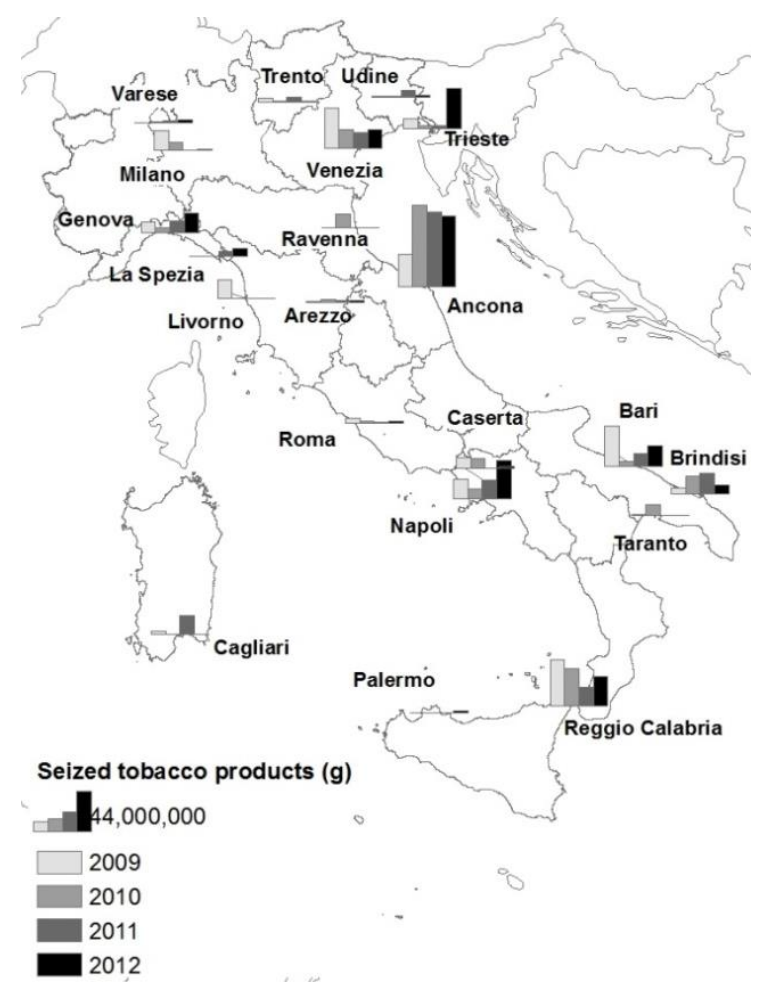

Source: author's elaboration

The review of the available information on the Italian illicit tobacco market points out a complex situation. While the media and official sources highlight the significant involvement of Italian and foreign criminal organizations in the ITTP, arguing that domestic mafias would earn nearly $€ 1$ bn from illicit tobacco, the existing evidence is partially at odds with the picture of a criminal market monopolized by the mafias and organized crime. It is so for several reasons. First, the illicit market has undergone significant changes in recent years. From high levels during the 1990s, it dropped to low ones at the beginning of the 2000s; in recent years, most available estimates suggest a growth of illicit consumption. This is somewhat in contrast with the constant presence of organized crime in the country. Second, the existing data on seizures and non-domestic packs suggest that the levels of illicit trade may not relate only to a strong presence of the mafias and other criminal organizations. Data on 
seizures point out that the mafias are not the only actor at the wholesale distribution level. Most of the seizures in the last three years occurred in the port of Ancona, a city with low mafia presence. Conversely, ports where the mafias may have stronger control, such as in Naples, Bari, and Reggio Calabria, show an irregular trend in the seizures. The data on empty packs point out that, at the retail level, the ITTP may reach high levels in areas with and without strong mafia control. While Campania (region of origin of the Camorra) has high levels of non-domestic packs, Calabria and Sicilia (origin of the 'Ndrangheta and Cosa Nostra respectively) are below the national average. Finally, the data also show significant changes in the ITTP across time and regions. For example, the prevalence of non-domestic packs in Naples passed from $8 \%$ in the fourth quarter of 2011 to $46 \%$ and $50 \%$ in the second and fourth quarter of 2012, respectively; in Rome, it passed from $3.5 \%$ in the second quarter of 2009 to $10 \%$ in the last quarter of the same year.

The contrast between public opinion and empirical evidence is problematic and prevents better understanding of the functioning of the ITTP. There is a need for more studies on the factors driving the illicit market across time and space within the same country. However, such analyses require better estimates of the size of the illegal tobacco market providing regional estimates of the volume and revenues generated by the ITTP. This study aims to fill this gap by developing a methodology with which to estimate the regional volumes and revenues from the illicit cigarette market and applying it to Italy for the period 2009-2012. 


\section{Methodology to estimate the illicit cigarette market}

\section{Data}

The methodology used to estimate the illicit cigarette market was mainly based on the national estimate of the ITTP in Italy by KPMG's Project Star 2012 report, on empty pack surveys data provided by Philip Morris International, and other publicly available data (Table 1 ). ${ }^{76}$ The estimates refer merely to the cigarette market and exclude hand rolling tobacco (HRT), due to the lack of data. ${ }^{77}$

Table 1. Data for estimating the illicit trade in tobacco products in Italy

\begin{tabular}{|c|c|c|c|c|c|}
\hline Variable & & Description & Disaggregation & Years & Source \\
\hline Smokers & $\mathrm{Sm}$ & $\begin{array}{c}\text { Persons }>13 \text { years old } \\
\text { who declare to smoke } \\
\text { per } 100 \text { residents with } \\
\text { the same } \\
\text { characteristics }\end{array}$ & Region & $\begin{array}{l}2009- \\
2012\end{array}$ & I.Stat, ISTAT \\
\hline Inhabitants & Pop & $\begin{array}{l}\text { Residents }>13 \text { years } \\
\text { old at } 31 \text { December }\end{array}$ & Region & $\begin{array}{l}2009- \\
2012\end{array}$ & Geo Demo, ISTAT \\
\hline $\begin{array}{l}\text { Non- } \\
\text { domestic } \\
\text { packs }\end{array}$ & ND & $\begin{array}{l}\text { Discarded packs of } \\
\text { foreign origin }\end{array}$ & 41 Italian cities & $\begin{array}{l}2009- \\
2012\end{array}$ & $\begin{array}{c}\text { Empty packs } \\
\text { surveys by } \\
\text { MSIntelligence, } \\
\text { provided by PMI }\end{array}$ \\
\hline $\begin{array}{l}\text { Illicit } \\
\text { market }\end{array}$ & $\mathrm{IM}$ & $\begin{array}{l}\text { Contraband and } \\
\text { counterfeiting }\end{array}$ & National & $\begin{array}{l}2009- \\
2012\end{array}$ & $\mathrm{KPMG}^{78}$ \\
\hline $\begin{array}{l}\text { Prices in } \\
\text { illicit } \\
\text { market }\end{array}$ & $\mathrm{P}$ & Price per pack & $\mathrm{n} / \mathrm{a}$ & $\mathrm{n} / \mathrm{a}$ & $\begin{array}{l}\text { Press, open sources } \\
\text { and contact with } \\
\text { stakeholders }\end{array}$ \\
\hline
\end{tabular}

Given the above mentioned concerns about the use of industry-related sources, the choice of KPMG's Project Star and EPSs data was mainly due to the lack of comparable alternatives.

Despite the already mentioned criticisms to its methodology, Project Star is the only source of annual estimates of the ITTP in Italy through the application of the same model. Its usefulness was recently acknowledged even in the very critical review by Gilmore and colleagues. ${ }^{79}$ The adoption of different estimates as a starting point would have yielded different results. However, alternative sources were discarded for several 
reasons: some estimates referred to a short time period and were outdated (e.g. Nomisma); the information available on the methodology used to obtain some estimates did not allow assessment of their reliability (e.g. EMI); consumer surveys are not available at subnational level and are unreliable on sensitive issues, such as the purchase of illicit products. The selection of Project Star's national figures as a starting point does not disregard the problems of the method proposed by KPMG. There is the need of alternative, independent and fully transparent estimates of the ITTP. Yet, until significant investments are made in this direction, Project Star is likely to remain the only available source. As the main goal of this study was to create a methodology providing annual estimates of the ITTP at the subnational level, future better estimates at the national level may replace Project Star's figures.

Industry-sponsored EPSs have a number of advantages and disadvantages. Among the advantages, EPSs have large samples and are repeated periodically. The Italian surveys gather and analyze a sample of 10,000 cigarettes packs from all the 41 cities with more than 100,000 inhabitants (covering 16 out of 20 regions) two times a year (every second and fourth quarter, thus avoiding the summertime, which may be biased by tourist in- and outflows). The collection plans are designed to cover different parts of the cities. Each city is divided into 5 sectors (North, South, East West, and Center), and each sector is broken down into circular areas of $500 \mathrm{~m}$ radius. To ensure the statistical robustness of the sample, a sample of thirty packs is collected in each area. ${ }^{80}$ For example, Figure 4 shows the collection areas for the city of Milan. The surveys cover most of the residential areas of the city, avoiding concentration in the city center (where tourist presence may boost the prevalence of non-domestic packs) and areas of lower socio-economic conditions (where illicit consumption may be higher). Furthermore, EPSs are based on the actual packs and do not rely on consumers' 
perceptions and willingness to report. Currently, pack analysis enables identification of manufacturer, brand, country variant and whether the pack is counterfeit or an illicit white brand. This information enables some distinction among different types of illicit trade (contraband, counterfeit and illicit whites). Lastly, the most important advantage is that EPSs are the only source providing insight into city and regional differences in the prevalence of non-domestic packs, which enable the elaboration of estimates at the subnational level.

Figure 4. Collection points for the empty packs surveys in the city of Milan (20112012).

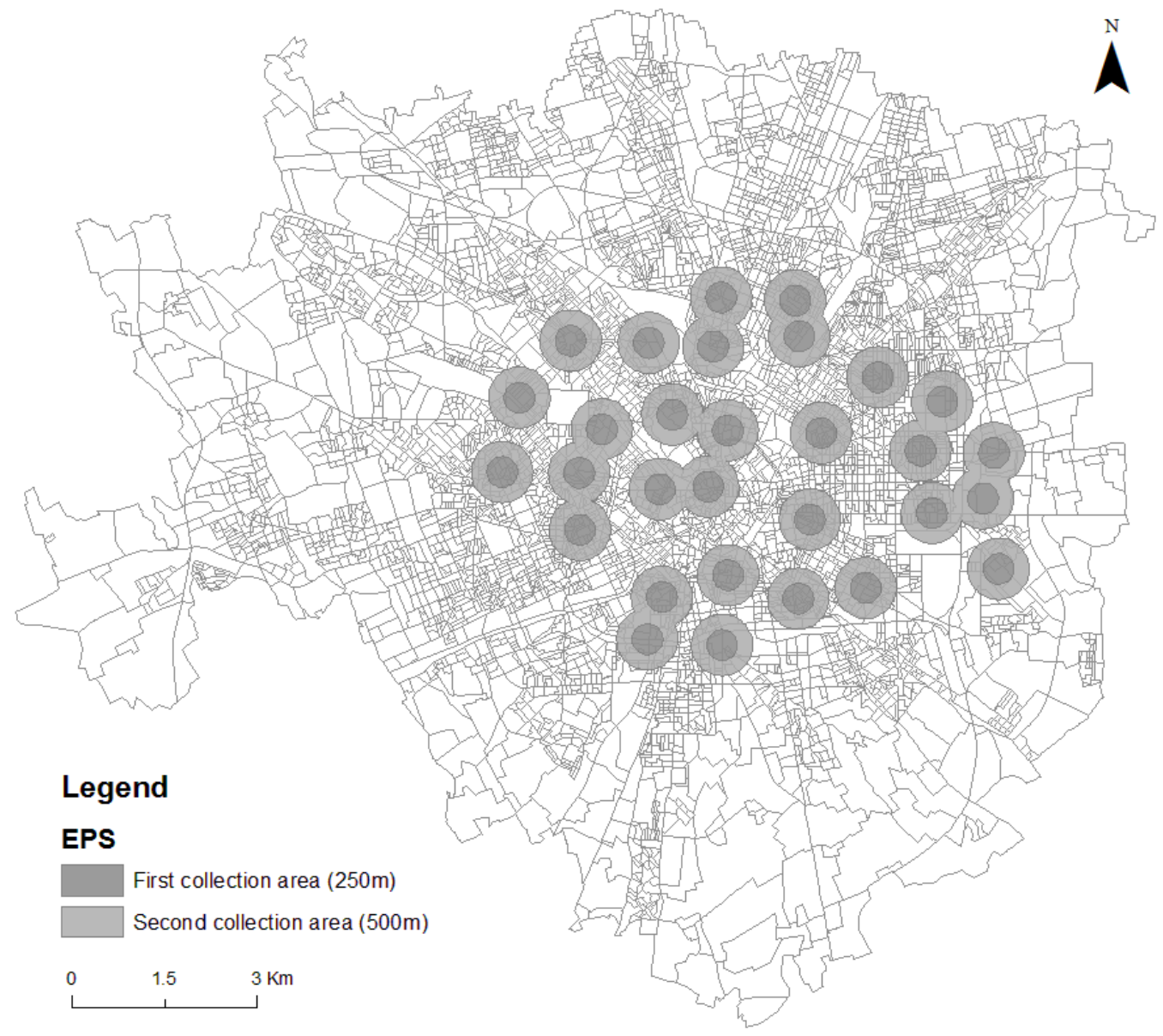

Source: author's elaboration

The literature has pointed out several disadvantages of industry-sponsored EPSs. ${ }^{81}$ First, the surveys measure the prevalence of non-domestic products, which inevitably include legitimately purchased cigarettes (e.g. by foreign tourists or nationals 
traveling abroad). Also, EPSs exclude illicit domestic products (e.g. contraband cigarettes of Italian variants) which may underestimate the illicit market. However, there seems to be no practicable method for a more precise identification of illicit products, as "it is impossible to discriminate between smuggled goods, legal crossborder purchases and illegal cross-border purchases. The only possible distinction that can be made thanks to [pack surveys] is between counterfeit packs and others" ${ }^{82}$ Indeed, other independent surveys analyzed whether packs bore tax stamps required for the sale in the place of collection. This approach however focuses on tax avoidance (whether local taxes were paid or not), which may also be the result of legal purchases. ${ }^{83}$ For this reason, the share non-domestic products should not be considered as a direct estimate of the illicit market, particularly in countries with high cigarette prices and regions bordering countries with lower prices. ${ }^{84}$ Yet, notwithstanding these issues, the share of non-domestic products may be considered a good of approximation of the prevalence of illicit tobacco within the same country.

Second, the literature remarked that the information on the methodology is incomplete. The samples should be representative of the national population, while in some cases they may over-represent areas of particular interest for the manufacturers. Surveys are conducted only in large and medium cities and there is insufficient information on the criteria for the selection of the streets. Some have contended that these methodological steps may be designed to inflate the prevalence of non-domestic packs, due to a higher presence of tourists, foreign students, and people of lower socioeconomic conditions. ${ }^{85}$ While these concerns are important, the above exposed details on the methodology of the Italian EPSs suggest that the results should be reliable and also more robust than some independent surveys, where only a few packs where collected in some of the sampled city areas. ${ }^{86}$ Inspection of the collection areas of 
industry-sponsored EPSs in the city of Milan showed a preference towards residential, non-peripheral and non-tourist areas (Figure 4). Furthermore, most of the limitations of current surveys are also due to their costs in terms of money and time. According to PMI, each EPSs wave costs more than $€ 70,000$. Coverage of rural areas and more detailed analyses on packs may significantly increase the costs of the surveys.

Third, EPSs exclude other tobacco products such as hand rolling tobacco, and do not include homes and workplaces. These limitations are likely due to feasibility and cost constraints.

Lastly, the use of industry-sponsored sources may inadvertently support the policy agenda of tobacco manufacturers, accused of exploiting the issue of illicit trade for their commercial purposes ${ }^{87}$ However, the Italian EPSs are collected using a specifically designed methodology which does not appear aimed at inflating the prevalence of non-domestic products, e.g. by focusing on specific hotspot cities, tourist areas or neighborhoods with low socio-economic conditions. Whereas the industry should be more transparent on the methodology of the EPSs and should improve the quality of the data, the surveys are currently the only available annual source on the consumption of non-domestic cigarettes.

The above considerations suggest that EPSs data should be treated with caution and that further efforts are needed to refine their methodologies. Yet, the available information on the Italian EPSs point out that these data can be used as a proxy of the regional prevalence of the illicit market. As already argued, this study has adopted EPSs due to the lack of better alternatives. If new, independent, and more reliable proxies become available, they may be integrated in the methodology with limited effort. 


\section{Estimates}

This study estimated the volumes and revenues of the illicit cigarette market for the period 2009-2012 owing to the availability of data for these years.

For every year, the national illicit market $\left(\mathrm{IM}_{\text {nat }}\right)$ as estimated by KPMG was divided among the Italian regions in proportion to the number of smokers, in turn obtained by multiplying the percentage of smokers $\left(\mathrm{Sm}_{\mathrm{reg}}\right)$ by the population $>13$ years old in each region $\left(\right.$ Pop $\left._{\text {reg }}\right)$.

$$
\mathrm{IM}_{\text {reg }}=\frac{\mathrm{IM}_{\text {nat }} \cdot \mathrm{Sm}_{\text {reg }} \cdot \mathrm{Pop}_{\text {reg }}}{\mathrm{Sm}_{\text {nat }} \cdot \mathrm{Pop}_{\text {nat }}}
$$

The resulting $\mathrm{IM}_{\mathrm{reg}}$ estimated the regional size of the ITTP, assuming that all regions have the same prevalence of illicit tobacco consumption. This assumption, however, appears implausible: the analysis of the Italian EPSs presented in Figure 2 highlighted that non-domestic packs are distributed unequally across the country, which may suggest that illicit consumption may be concentrated unevenly.

The $\mathrm{IM}_{\mathrm{reg}}$ were adjusted to account for these differences in the regional illicit consumption. The proxy for the regional levels of illicit trade was the regional share of "non-domestic" packs collected by empty pack surveys $\left(\mathrm{ND}_{\text {reg }}\right)$. The regional share was the average of the non-domestic share in the two surveys per year (one in the second quarter and one in the last quarter). The non-domestic share was the ratio between the sum of non-domestic packs and the sum of the total packs collected in all the cities in a region. $^{88}$

The regional illicit markets were weighted for the ratio between the ND in the region and the average of the regional ND share. To return the sum of the regional illicit 
markets to the national total, the values were divided by their sum and multiplied by $\mathrm{IM}_{\text {nat }}$, obtaining the regional illicit markets adjusted $\left(\mathrm{IMadj}_{\mathrm{reg}}\right){ }^{89}$

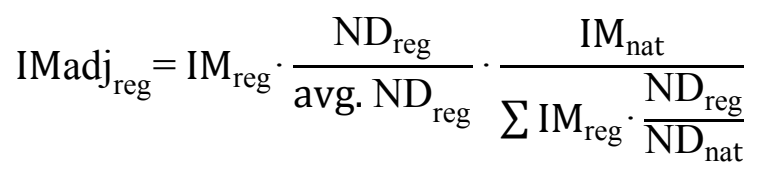

Regional revenues from the illicit trade in tobacco products (IMrev $v_{\text {reg }}$ ) were obtained by dividing the values of IMadj $\mathrm{j}_{\mathrm{reg}}$ by 20 (the most sold pack size in Italy) and multiplying the result by the price of an illicit 20-cigarette pack. After reviewing open sources and press releases, and after interviewing stakeholders (law enforcement, prosecution and industry experts), the study adopted a minimum illicit price of $€ 2.75$ and a maximum one of $€ 3.5$ per 20-cigarette pack. The selection of these prices is reasonable, since they are below the prices of the most popular brands in Italy. During the same period, the price of a 20-cigarette pack of Marlboro (the most sold brand in Italy) rose from $€ 4.3$ (2008) to $€ 5$ (end 2012)..$^{90}$ This is also in line with the range of prices of illicit cigarettes identified by Joossens and colleagues. ${ }^{91}$

$$
\begin{gathered}
\operatorname{IMrev}_{\text {reg }_{\text {max }}}=\frac{\text { IMadj }_{\text {reg }}}{20} \cdot € 3.5 \\
\text { IMrev }_{\text {reg }_{\text {min }}}=\frac{\text { IMadj }_{\text {reg }}}{20} \cdot € 2.75
\end{gathered}
$$

\section{Results and discussion}

Table 2 shows the regional estimates of the volumes and revenues of the ITTP for the period 2009-2012. The national revenues from the ITTP increased by nearly 2.5 times during the period observed, rising from $€ 532 \mathrm{mn}$ in 2009 (max estimate) to $€ 1,275 \mathrm{mn}$ in 2012 (max estimate). The estimated volumes of the illicit market correspond to 
significant tax losses. The revenue loss for the Italian government in the period was approximately $€ 423 \mathrm{mn}$ in 2009 , €650 $\mathrm{mn}$ in $2010, € 739 \mathrm{mn}$ in 2011 , and $€ 1,184 \mathrm{mn}$ in 2012 , totaling $€ 2,995 .{ }^{92}$ Considering that the total tax collected in Italy on cigarettes is in the range of $€ 14,000 \mathrm{mn}$ per year, the ITTP may have an impact of up to approximately $8.5 \%$ of the total revenues from cigarettes. ${ }^{93}$

Table 3. Estimates of the volume (mn sticks) and minimum/maximum revenues (mn€) of the illicit tobacco market by Italian region (2009-2012).

\begin{tabular}{|c|c|c|c|c|c|c|c|c|c|c|c|c|}
\hline \multirow[b]{4}{*}{ Abruzzo } & \multicolumn{3}{|c|}{2009} & \multicolumn{3}{|c|}{2010} & \multicolumn{3}{|c|}{2011} & \multicolumn{3}{|c|}{2012} \\
\hline & \multicolumn{2}{|c|}{ Volume $\mathrm{F}$} & Revenue & \multirow{2}{*}{$\begin{array}{c}\text { Volume } \\
\text { Madj }\end{array}$} & \multicolumn{2}{|c|}{ Revenue } & \multirow{2}{*}{$\begin{array}{c}\text { Volume } \\
\text { IMadj }\end{array}$} & \multicolumn{2}{|c|}{ Revenue } & \multirow{2}{*}{$\begin{array}{c}\text { Volume } \\
\text { IMadj }\end{array}$} & \multicolumn{2}{|c|}{ Revenue } \\
\hline & Madj & IMreV $_{\text {min }}$ & in $\mathbb{M M r e V}_{\max }$ & & IMrev $_{\text {min }}$ & IMrev $_{\max }$ & & $\mathbb{M}_{\text {rev }}$ min & IMrev $_{\max }$ & & IMrev $_{\text {min }}$ & IMrev $_{\text {max }}$ \\
\hline & 141.5 & 19.5 & 24.8 & 58.7 & 8.1 & 10.3 & 52.0 & 7.2 & 9.1 & 166.2 & 22.9 & 29.1 \\
\hline Basilicata & 22.6 & 3.1 & 4.0 & 43.8 & 6.0 & 7.7 & 42.4 & 5.8 & 7.4 & 31.7 & 4.4 & 5.5 \\
\hline Calabria & 46.9 & 6.5 & 8.2 & 109.3 & 15.0 & 19.1 & 80.5 & 11.1 & 14.1 & 84.2 & 11.6 & 14.7 \\
\hline Campania & 310.4 & 42.7 & 54.3 & 470.6 & 64.7 & 82.4 & 637.2 & 87.6 & 111.5 & $\begin{array}{r}2085 . \\
7\end{array}$ & 286.8 & 365.0 \\
\hline $\begin{array}{l}\text { Emilia- } \\
\text { Romagna }\end{array}$ & 261.7 & 36.0 & 45.8 & 259.1 & 35.6 & 45.4 & 247.3 & 34.0 & 43.3 & 325.3 & 44.7 & 56.9 \\
\hline $\begin{array}{l}\text { Friuli-V€ } \\
\text { Giulia }\end{array}$ & 125.7 & 17.3 & 22.0 & 95.7 & 13.2 & 16.7 & 127.8 & 17.6 & 22.4 & 370.8 & 51.0 & 64.9 \\
\hline Lazio & 397.8 & 54.7 & 69.6 & 286.6 & 39.4 & 50.2 & 307.5 & 42.3 & 53.8 & 416.3 & 57.2 & 72.9 \\
\hline Liguria & 101.4 & 13.9 & 17.7 & 122.4 & 16.8 & 21.4 & 107.6 & 14.8 & 18.8 & 85.3 & 11.7 & 14.9 \\
\hline Lombardia & 365.0 & 50.2 & 63.9 & $\begin{array}{r}1107 . \\
0\end{array}$ & 52.2 & 93.7 & $\begin{array}{r}1143 . \\
0\end{array}$ & 57.2 & 200.0 & $\begin{array}{r}1124 . \\
3\end{array}$ & 154.6 & 196.8 \\
\hline Marche & 90.9 & 12.5 & 15.9 & 123.5 & 17.0 & 21.6 & 194.2 & 26.7 & 34.0 & 116.7 & 16.0 & 20.4 \\
\hline Molise & 18.8 & 2.6 & 3.3 & 19.7 & 2.7 & 3.5 & 18.5 & 2.5 & 3.2 & 25.6 & 3.5 & 4.5 \\
\hline Piemonte & 204.2 & 28.1 & 35.7 & 348.8 & 48.0 & 61.0 & 437.7 & 60.2 & 76.6 & 412.0 & 56.7 & 72.1 \\
\hline Puglia & 123.5 & 17.0 & 21.6 & 429.6 & 59.1 & 75.2 & 208.6 & 28.7 & 36.5 & 225.3 & 31.0 & 39.4 \\
\hline Sardegna & 95.3 & 13.1 & 16.7 & 115.2 & 15.8 & 20.2 & 2 118.3 & 16.3 & 20.7 & 174.1 & 23.9 & 30.5 \\
\hline Sicilia & 139.3 & 19.2 & 24.4 & 261.6 & 36.0 & 45.8 & 197.9 & 27.2 & 34.6 & 466.7 & 64.2 & 81.7 \\
\hline Toscana & 218.1 & 30.0 & 38.2 & 282.5 & 38.8 & 49.4 & 195.8 & 26.9 & 34.3 & 327.6 & 45.0 & 57.3 \\
\hline $\begin{array}{l}\text { Trentino-Alto } \\
\text { Adige }\end{array}$ & 30.1 & 4.1 & 5.3 & 77.0 & 10.6 & 13.5 & 131.1 & 18.0 & 22.9 & 94.2 & 13.0 & 16.5 \\
\hline Umbria & 75.5 & 10.4 & 13.2 & 70.0 & 9.6 & 12.2 & 90.7 & 12.5 & 15.9 & 63.9 & 8.8 & 11.2 \\
\hline Valle d'Aos & 4.8 & 0.7 & 0.8 & 8.9 & 1.2 & 1.6 & 8.9 & 1.2 & 1.6 & 8.7 & 1.2 & 1.5 \\
\hline Veneto & 266.5 & 36.6 & 46.6 & 259.8 & 35.7 & 45.5 & 463.0 & 63.7 & 81.0 & 685.4 & 94.2 & 119.9 \\
\hline Italy & 3040 & 418.0 & 532.0 & 4550 & 625.6 & 796.3 & 4810 & 661.4 & 841.7 & 7290 & $\begin{array}{r}1002 . \\
4\end{array}$ & $\begin{array}{r}1275 \\
8\end{array}$ \\
\hline
\end{tabular}

Source: author's calculations

Over the years, the largest regional illicit markets changed among the most populated 
Italian regions (Lazio in 2009, Lombardia in 2010 and 2011, Campania in 2012) (Figure

5, left map). The values were normalized by the smoking population to take the different sizes of the regions into account (Figure 5, right map). At the national level, the illicit trade rose from an equivalent of 12.6 20-cigarette packs per smoker in 2009 to 32.2 in $2012 .^{94}$ Among the regions, in the four years considered, only Friuli-Venezia Giulia always recorded normalized volumes higher than the national ones. Three other regions had higher values in three out of four years (Campania, Marche and Veneto). In part, the estimates for Friuli-Venezia Giulia and Marche may be due to the data, since the EPSs for these regions surveyed only the regional capitals of Trieste and Ancona, which are located on the coast and close to countries with lower cigarette prices.

These figures suggest that the regional prevalence of the ITTP is mostly related to the availability of illicit tobacco due to the proximity to countries with lower prices or to the presence of large transport infrastructures. Friuli-Venezia Giulia and Veneto are close to Slovenia, where cigarettes are cheaper. ${ }^{95}$ While consumers may legitimately purchase cigarettes in the neighboring country, the easy access provides also an opportunity for the development of small scale contraband or bootlegging. The removal of border controls between Italy and Slovenia (due to the European Union policies) may have further reduced the risks for individuals willing to engage in the ITTP. For example, it may be possible to drive a car across the border, fill it with cigarette cartons, and re-enter Italy with a very low risk of being controlled. Furthermore, all the abovementioned four regions have important ports (Trieste, Venice, Ancona and Naples), which may function as important gateways for the entry of illicit tobacco into Italy. This may also make illicit products more available in the port cities.

The findings also suggest that the mafias may be an important driver of the ITTP, although not the only one. In Campania, the significant growth of the illicit trade 
in 2012 suggests a correlation with the strong presence of the Camorra, a mafia with a consolidated expertise in cigarette smuggling. The sudden increase in a single year, however, points out that mafia control alone is not a sufficient condition. More probably, the Camorra has been able to exploit its traditional expertise in cigarette smuggling, but also some criminal opportunities which have occurred in 2012. For example, new methods of smuggling may have been adopted in the port of Naples, as signaled by an increase of the seizures, although inferior to the increase of the estimated prevalence of illicit cigarettes. Other regions with a traditionally strong presence of the mafias (Sicily, Calabria and Puglia) did not show a similar growth pattern. Also the seizures in the main ports of these regions had irregular trends, despite the strong mafia control over the cities of Palermo and Reggio Calabria. The differences across traditional mafia regions may further confirm that the mafias are not a sufficient condition for the development of large illicit markets. ${ }^{96}$

The estimates of the ITTP were high also in regions with a very low presence of the mafias. Contrary to Campania, Friuli-Venezia Giulia, Veneto and Marche had a very low presence of mafias, but high estimates of the ITTP. ${ }^{97}$ This confirms that the presence of the mafias is not only insufficient, but unnecessary for the development of the ITTP at the regional level. As discussed above, the causes of the consumption of illicit cigarettes in these regions may be due to the proximity to Slovenia. 
Figure 5. Illicit cigarette market per region in value (minimum estimates, mn€) and equivalent 20-cigarette packs per smoker (2009-2012).
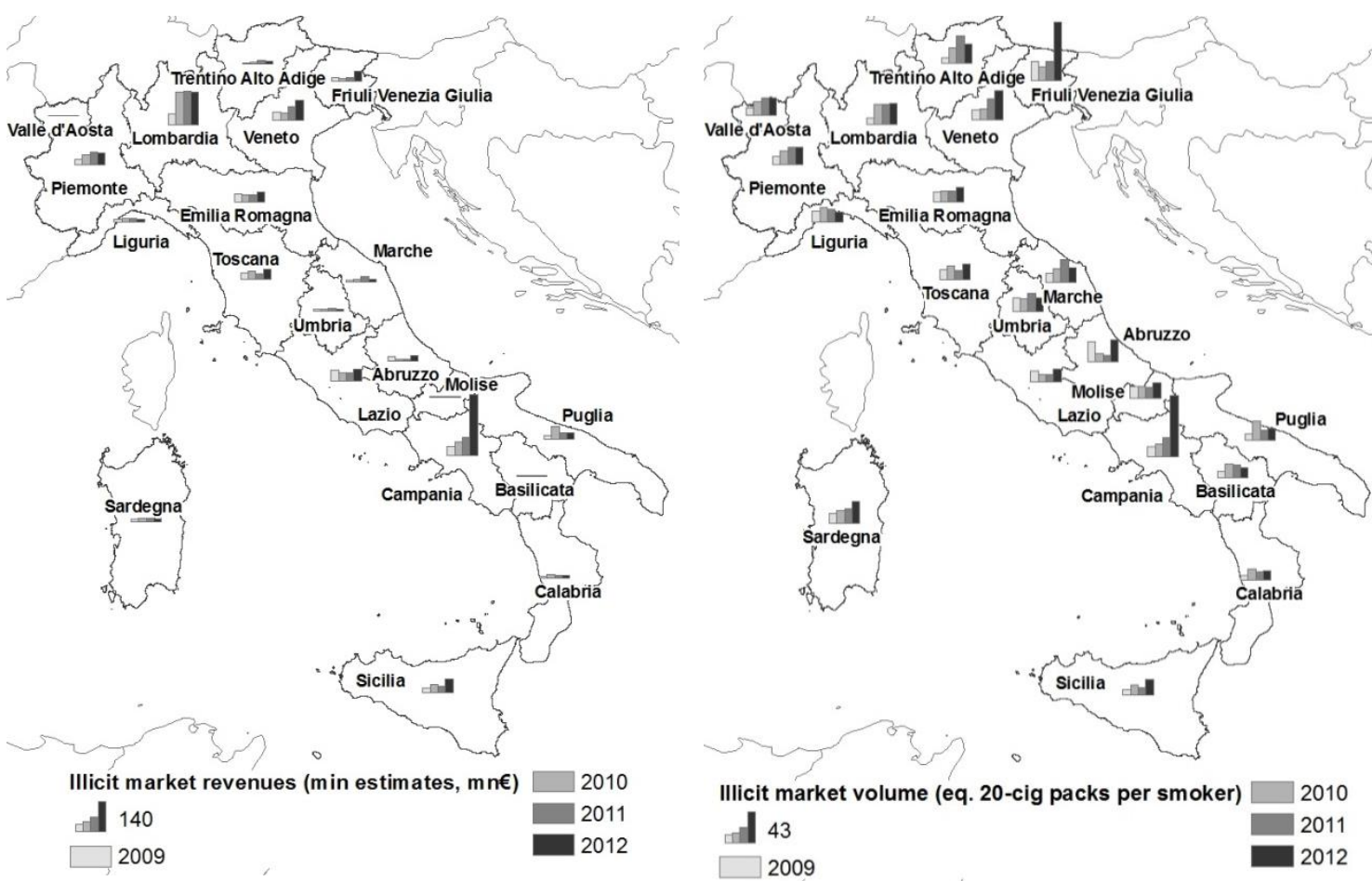

Source: author's calculations

Another significant characteristic is the growth pattern of the ITTP across the years.

From 2009 to 2011, the regional values were concentrated around the average (average packs per smoker $13.99,18.54$ and 20.89 , with st. dev of 5.69, 4.39 and 8.41, respectively). This reveals a general increase in most regions. In 2012, the growth was significant, mainly due to three already-mentioned regions: Friuli-Venezia Giulia and Campania exceeded 80 packs per smoker, while Veneto went up to 41 (2012 regional average was 29.35 , st. dev 19.67). Without these regions, the national increase would have been in the range of approximately 1 pack per smoker.

The estimation of the revenue generated by the ITTP does not provide support to the claim that in 2010 the mafias would have gained up to $€ 0.9$ bn from illicit cigarettes. ${ }^{98}$ The total estimated revenues at the retail level for the same year range 
between $€ 625 \mathrm{mn}$ and $€ 796 \mathrm{mn}$, well below the alleged mafia revenues. Furthermore, not all such revenues should be attributed to the mafias, given the variety of actors which may be involved in the different stages of the illicit market.

Overall, the application of the proposed methodology to Italy call for the adoption of different policy measures for the prevention and control of the ITTP. In the regions close to Slovenia, better controls may be implemented to ensure that cheaper foreign cigarettes are not smuggled into the country. Probably, this may require more efforts in the cooperation between Italian and Slovenian authorities. In Campania, further analyses should identify the opportunities which triggered the boom of the illicit market in 2012. For example, the implementation of new tracking systems within the port of Naples may contribute to effectively reduce the risk of smuggling. Also, further research should assess whether the illicit trade in the region is controlled, at least in part, by the Camorra, given the solid expertise of this mafia in the smuggling of cigarettes.

\section{Conclusions}

This study has described a methodology for the estimation of the illicit cigarette market at the subnational level. The methodology is based mainly on data produced with the financial support of the tobacco industry. The review of available alternatives highlighted that independent sources do not allow estimation of the regional prevalence across different years and have problems of reliability (e.g. consumers survey are likely to underestimate illicit consumption, due to respondents' underreporting). Concerns about possible biases by the tobacco industry are legitimate and should not be underestimated. The tobacco industry should be more transparent on the methodologies adopted in the study it supports, which would also contribute to its attempts to present itself as a reliable partner in the fight against illicit tobacco. Since the development of independent measurements with a level of detail comparable to that of industry- 
supported sources appears far to come, at present the latter ones provide the only possibility to estimate the prevalence of the ITTP at the subnational level across different years and countries.

Notwithstanding the possible limitations of the data, the proposed estimation method requires a relatively limited number of sources. The starting points were Project Star's national estimates of the illicit trade (currently available for 27 EU Member States), which may be replaced by other, independent assessments whenever they will be developed. Data for the regional estimation are the smoking population and nondomestic packs found by empty pack surveys. The former data are normally available, while the EPSs are conducted by the tobacco manufacturers in a number of countries and disseminated through media and reports, but often in aggregated form. Also EPSs data may be replaced with better data, if available. The limited requirements in terms of data may allow application of the method to other countries, which may provide insight into the regional prevalence of the illicit cigarette market across time and space.

Application of the method to Italian regions from 2009 to 2012 yielded insight into the chronological and spatial evolution of the ITTP. Indeed, while most publicly available estimates are at the national level, the regional estimates for Italy reveal that the illicit trade varies significantly across time and regions. The results show that the increase at the national level was driven by a general growth across most regions in the first three years, and by an increase concentrated in only three regions in 2012. Also, the analysis points out that a strong presence of the mafias in a region is not a sufficient condition for the growth of the ITTP. This contrasts with the opinion of the media and public agencies, which frequently attributes the illicit tobacco trade to organized crime. This suggests that illicit cigarettes have a complex market which is influenced by a number of factors. 


\section{References}

Allen, Elizabeth. The Illicit Trade in Tobacco Products and How to Tackle It.

Washington D.C: International Tax and Investment Center, 2011.

Almares. Poland Market Survey: Empty Discarded Pack Collection March - April 2012.

Warsaw: Almares Institute for Consulting and Market Research, 2012.

—. Poland Market Survey: Empty Discarded Pack Collection, August-September

2011. Warsaw: Almares Institute for Consulting and Market Research, 2011.

http://www.bat.com.pl/group/sites/bat_84bcnd.nsf/vwPagesWebLive/DO84BJH5/\$FIL

E/medMD8S8KF7.pdf.

—. Poland Market Survey: Empty Discarded Pack Collection, October-

November 2011. Warsaw: Almares Institute for Consulting and Market Research, 2011.

Antonopoulos, Georgios A. "Cigarette Smugglers: A Note on Four 'Unusual

Suspects'.” Global Crime 8, no. 4 (2007): 393.

Arlacchi, Pino. Addio Cosa Nostra: La vita di Tommaso Buscetta. Milano: Rizzoli, 1994.

_. Gli uomini del disonore: La mafia siciliana nella vita del grande pentito Antonino Calderone. Milano: Mondadori, 1992.

Beare, Margaret E. “Organized Corporate Criminality: Corporate Complicity in Tobacco Smuggling.” In Critical Reflections on Transnational Organized Crime, Money Laundering and Corruption, edited by Margaret E Beare. Toronto: University of Toronto Press, 2003.

Beelman, Maud S., Bill Birnbauer, Duncan Campbell, William Marsden, Erik Schelzig, and Leo Sisti. "Tobacco Companies Linked to Criminal Organizations in Lucrative Cigarette Smuggling.” The Center for Public Integrity, March 3, 2001. http://projects.publicintegrity.org/Content.aspx?context=article\&id=351. 
Beelman, Maud S., Duncan Campbell, Maria Teresa Ronderos, and Erik Schelzig. "Major Tobacco Multinational Implicated In Cigarette Smuggling, Tax Evasion, Documents Show.” The Center for Public Integrity, January 31, 2000.

http://projects.publicintegrity.org/report.aspx?aid=335.

Ben Lakhdar, Christian. "Quantitative and Qualitative Estimates of Cross-border Tobacco Shopping and Tobacco Smuggling in France.” Tobacco Control 17, no. 1 (February 2008): 12-16. doi:10.1136/tc.2007.020891.

Ben Lakhdar, Christian, Aurélie Lermienier, and Nicolas Vaillant. Estimation Des Achats Transfrontaliers de Cigarettes 2004-2007. Tendances. OFDT, March 2011. Blecher, Evan. "A Mountain or a Molehill: Is the Illicit Trade in Cigarettes Undermining Tobacco Control Policy in South Africa?" Trends in Organized Crime 13, no. 4 (April 30, 2010): 299-315.

Blecher, Evan, Alex Liber, Hana Ross, and Johanna Birckmayer. "Euromonitor Data on the Illicit Trade in Cigarettes." Tobacco Control (June 21, 2013).

doi:10.1136/tobaccocontrol-2013-051034.

Calderoni, Francesco, Monica Angelini, Marco De Simoni, Serena Favarin, and Martina Rotondi. Italy. The Factbook on the Illicit Trade in Tobacco Products 2. Trento:

Transcrime - Università degli Studi di Trento, 2013.

http://transcrime.cs.unitn.it/tc/1132.php.

- Italy. The Factbook on the Illicit Trade in Tobacco Products 2. The Factbook. Trento, Italy: Transcrime - Università degli Studi di Trento, 2013.

Calderoni, Francesco, Serena Favarin, Ombretta Ingrascì, and Anne Smit. United Kingdom. The Factbook on the Illicit Trade in Tobacco Products 1. Trento: Transcrime - Università degli Studi di Trento, 2013. http://transcrime.cs.unitn.it/tc/1104.php. 
Calderoni, Francesco, Ernesto U. Savona, and Serena Solmi. Crime Proofing the Policy Options for the Revision of the Tobacco Products Directive: Proofing the Policy Options Under Consideration for the Revision of EU Directive 2001/37/EC Against the Risks of Unintended Criminal Opportunities. Trento: Transcrime - Joint Research Centre on Transnational Crime, 2012.

Caneppele, Stefano, Ernesto U. Savona, and Alberto Aziani. Crime Proofing of the New Tobacco Products Directive. Trento: Transcrime - Joint Research Centre on Transnational Crime, September 2013.

Chaloupka, Frank J., and John A. Tauras. The Demand for Cigarettes in Ireland. Dublin: HSE National Tobacoo Control Office, August 2011.

Chernick, Howard, and David Merriman. "Using Littered Pack Data to Estimate Cigarette Tax Avoidance in NYC.” National Tax Journal 66, no. 3 (September 2013): $635-668$.

Ciecierski, Christina. “The Market for Legal and Illegal Cigarettes in Poland: A Closer Look at Demand and Supply-Side Characteristics.” Northeastern Illinois University, University of Illinois at Chicago, 2007. http://r4d.dfid.gov.uk/PDF/Outputs/RITC/Grant_223_Smuggling_in_PL_Manuscrip.pd f.

Coker, Dale. "Smoking May Not Only Be Hazardous to Your Health, but Also to World Political Stability: The European Union's Fight Against Cigarette Smuggling Rings That Benefit Terrorism." European Journal of Crime, Criminal Law and Criminal Justice 11 (2003): 350.

CPA. Relazione sul fenomeno criminale del contrabbando di tabacchi lavorati esteri in Italia e in Europa - Relatore On. Alfredo Mantovano. Roma: Commissione 
parlamentare di inchiesta sul fenomeno della Mafia e delle altre associazioni criminali similari, March 6, 2001.

—. Relazione sul traffico mafioso di tabacchi e stupefacenti nonché sui rapporti tra mafia e gangsterismo italo-americano (Relatore Zuccalà). Roma: Commissione Parlamentare di inchiesta sul fenomeno della mafia in Sicilia, February 4, 1976.

—. Relazione sullo stato della lotta alla criminalità organizzata nella provincia di Brindisi (Rel. Del Turco). Roma: Commissione Parlamentare di inchiesta sul fenomeno mafia e delle altre associazioni criminali similari, Luglio 1999.

Di Lucia, Massimiliano. Interview with Massimiliano Di Lucia, Guardia di Finanza. Phone call, June 24, 2013.

DIA. Esito Attività Di Indagine Svolta Sul Conto Di Djukanovic Milo + 4. N. 125/BA/2 ${ }^{\circ}$ SN. 125/BA/2 ${ }^{\circ}$ Sett. Inv. Giud. /H5. 148-1/ 1379 Di Prot.ett. Inv. Giud. /H5. 148-1/ 1379 Di Prot. Bari: Direzione Investigativa Antimafia - Centro operativo di Bari, February 2, 2005.

DNA. Relazione annuale sulle attività svolte dal Procuratore nazionale antimafia e dalla Direzione nazionale antimafia nonché sulle dinamiche e strategie della criminalità organizata di tipo mafioso nel periodo $1^{\circ}$ luglio 2011 - 30 giugno 2012. Roma: Direzione Nazionale Antimafia, Dicembre 2012.

—. Relazione annuale sulle attività svolte dal Procuratore nazionale antimafia e dalla Direzione nazionale antimafia nonché sulle dinamiche e strategie della criminalità organizzata di tipo mafioso nel periodo $1^{\circ}$ luglio 2005 - 30 giugno 2006. Roma: Direzione Nazionale Antimafia, 2006.

Euromonitor International. "Data on the Penetration of the Illicit Tobacco." Euromonitor International, 2013. 
- Illicit Trade in Tobacco Products 2012: Will the New Protocol Prove

Effective? Passport. Euromonitor International, 2013.

European Commission. "Manufactured Tobacco: Excise Duty Rates - European

Commission." Taxation and Customs Union, July 4, 2013.

http://ec.europa.eu/taxation_customs/taxation/excise_duties/tobacco_products/rates/inde X_en.htm.

Fooks, Gary Jonas, Silvy Peeters, and Karen Evans-Reeves. "Illicit Trade, Tobacco Industry-funded Studies and Policy Influence in the EU and UK." Tobacco Control 23, no. 1 (January 1, 2014): 81-83. doi:10.1136/tobaccocontrol-2012-050788.

Formisano, Anna Teresa, and Ludovico Vico. Commissione parlamentare d'inchiesta sui fenomeni della contraffazione e della pirateria in campo commerciale-Relazione sulla contraffazione nel settore del tabacco. Camera dei deputati, settembre 2012. Gallus, Silvano, Esteve Fernandez, Joanne Townsend, Anna Schiaffino, and Carlo La Vecchia. "Price and Consumption of Tobacco in Italy over the Last Three Decades." European Journal of Cancer Prevention 12, no. 4 (2003): 333-337.

Gallus, Silvano, Alessandra Lugo, Carlo La Vecchia, Paolo Boffetta, Frank J.

Chaloupka, Paolo Colombo, Laura Currie, et al. PPACTE, WP2: European Survey on Smoking. Final Report. Dublin: PPACTE Consortium, 2012.

http://www.ppacte.eu/index.php?option=com_docman\&task=doc_download\&gid=185 \&Itemid=29.

Gallus, Silvano, Irene Tramacere, Piergiorgio Zuccaro, Paolo Colombo, and Carlo La Vecchia. “Cigarette Smuggling in Italy, 2005-8.” Tobacco Control 18 (2009): 159-160. Gilmore, Anna B., Andy Rowell, Silvano Gallus, Alessandra Lugo, Luk Joossens, and Michelle Sims. "Towards a Greater Understanding of the Illicit Tobacco Trade in 
Europe: a Review of the PMI Funded 'Project Star' Report.” Tobacco Control

(December 11, 2013). doi:10.1136/tobaccocontrol-2013-051240.

Gutauskas, Aurelijus. "Lithuania." In Organized Crime and the Financial Crisis Recent

Trends in the Baltic Sea Region, edited by Walter Kegö, Erik Leijonmarck, and

Alexandru Molcean. Stockholm: Institute for Security and Development Policy, 2011.

Hornsby, Rob, and Dick Hobbs. "A Zone of Ambiguity: The Political Economy of

Cigarette Bootlegging.” British Journal of Criminology 47, no. 4 (July 1, 2007): 551 571.

ISTAT. "I.Stat: Movimento dei clienti negli esercizi ricettivi - dati annuali nazionali, ripartizionali e provinciali." ISTAT.IT, 2013. http://dati.istat.it/.

Ivanovic, Zeljko. "Speedboats, Cigarettes, Mafia and Montenegrin Democracy."

Institute for War and Peace Reporting, November 10, 2005. http://iwpr.net/report-

news/speedboats-cigarettes-mafia-and-montenegrin-democracy.

Joossens, Luk, Frank J. Chaloupka, David Merriman, and Ayda Yurekli. "Issues in the Smuggling of Tobacco Products.” In Tobacco Control in Developing Countries, edited by Frank J. Chaloupka and Prabhat Jha, 393-406. Oxford: Oxford University Press, 2000.

Joossens, Luk, Alessandra Lugo, Carlo La Vecchia, Anna B. Gilmore, Luke Clancy, and Silvano Gallus. "Illicit Cigarettes and Hand-rolled Tobacco in 18 European Countries: a Cross-sectional Survey.” Tobacco Control (December 10, 2012). doi:10.1136/tobaccocontrol-2012-050644.

Joossens, Luk, David Merriman, Hana Ross, and Martin Raw. How Eliminating the Global Illicit Cigarette Trade Would Increase Tax Revenue and Save Lives. Paris: International Union Against Tuberculosis and Lung Disease (The Union), 2009. 
Joossens, Luk, and Martin Raw. "Cigarette Smuggling in Europe: Who Really Benefits?" Tobacco Control 7, no. 1 (March 1, 1998): 66 -71.

_ . "From Cigarette Smuggling to Illicit Tobacco Trade." Tobacco Control 21, no. 2 (March 1, 2012): 230-234. doi:10.1136/tobaccocontrol-2011-050205.

—. "Progress in Combating Cigarette Smuggling: Controlling the Supply Chain." Tobacco Control 17, no. 6 (November 2008): 399-404.

Kegö, Walter, Erik Leijonmarck, and Alexandru Molcean, eds. Organized Crime and the Financial Crisis Recent Trends in the Baltic Sea Region. Stockholm-Nacka, Sweden: Institute for Security \& Development Policy, 2011. http://www.isdp.eu/images/stories/isdp-main-pdf/2011_kego-leijonmarckmolcean_organized-crime-and-the-financial-crisis.pdf. KPMG. Project Star 2010 Results. KPMG, August 22, 2011. http://www.pmi.com/eng/tobacco_regulation/illicit_trade/documents/Project_Star_2010 _Results.pdf.

—. Project Star 2012 Results. Project Star. KPMG, 2013. http://www.pmi.com/eng/media_center/media_kit/Documents/Project_Star_2012_Final _Report.pdf.

Lencucha, R., and C. Callard. "Lost Revenue Estimates from the Illicit Trade of Cigarettes: a 12-country Analysis.” Tobacco Control 20, no. 4 (February 17, 2011): $318-320$.

Levinson, Bruce. An Inquiry into the Nature, Causes and Impacts of Contraband Cigarettes. Washington D.C: Center for Regulatory Effectiveness, January 2011. Massari, Monica. La Sacra Corona Unita: Potere E Segreto. Saggi Tascabili Laterza 221. Roma: Laterza, 1998. 
Merriman, David. “The Micro-Geography of Tax Avoidance: Evidence from Littered Cigarette Packs in Chicago.” American Economic Journal: Economic Policy 2 (2010): $61-84$.

Merriman, David, Ayda Yurekli, and Frank J. Chaloupka. "How Big Is the Worldwide Cigarette-smuggling Problem?" In Tobacco Control in Developing Countries, edited by Frank J. Chaloupka and Prabhat Jha. Oxford: Oxford University Press, 2000.

NEMS Market Research. North of England Illicit Tobacco Survey. Billingham, UK: NEMS Market Research, 2009.

Niwserwis. Nielegalny Rynek Wyrobów Akcyzowych w Polsce. Warsaw, Poland, 2011. http://niwserwis.pl/artykuly/nielegalny-rynek-wyrobow-akcyzowych-w-polsce.html. Nomisma. La contraffazione delle sigarette in Italia primo rapporto nomisma. Bologna: Nomisma Società di Studi Economici S.p.A., 2011.

OCCRP. "Big Trouble at Big Tobacco." Organized Crime and Corruption Reporting Project, November 3, 2011.

http://www.reportingproject.net/troubles_with_big_tobacco/.

Paoli, Letizia. "Mafia and Organised Crime in Italy: The Unacknowledged Successes of Law Enforcement.” West European Politics 30, no. 4 (2007): 854.

—. "The Paradoxes of Organized Crime." Crime, Law and Social Change 37 (2002): 51-97.

Reidy, Padraic, and Keith Walsh. Economics of Tobacco: Modelling the Market for Cigarettes in Ireland. Dublin: The Office of the Revenue Commissioners, February 2011.

Russo, Giovanni. Interview with Giovanni Russo, Direzione Nazionale Antimafia. Corrispondenza elettronica, June 17, 2013. 
Seely, Antony. Cross Border Shopping and Smuggling. Great Britain, Parliament, House of Commons, Library, 2002.

Shafey, Omar, Michael Eriksen, Hana Ross, and Judith Mackay. The Tobacco Atlas.

Third Edition. Atlanta: American Cancer Society, 2009.

Shelley, Louise I., and Sharon A. Melzer. "The Nexus of Organized Crime and Terrorism: Two Case Studies in Cigarette Smuggling.” The International Journal of Comparative and Applied Criminal Justice 32, no. 1 (2008): 43-65.

Shelley, Louise I., and John T. Picarelli. "Methods Not Motives: Implications of the Convergence of International Organized Crime and Terrorism.” Police Practice and Research: An International Journal 3, no. 4 (2002): 305.

Shen, Anqi, Georgios A. Antonopoulos, and Klaus Von Lampe. “"The Dragon Breathes Smoke'.” British Journal of Criminology 50, no. 2 (March 1, 2010): 239 -258.

Siggens, Geoff, Paul Murray, and Sean Walters. West Midlands Regional Illicit Tobacco Survey. Billingham, UK: NEMS Market Research, 2010.

Sisti, Leo. "The Montenegro Connection: Love, Tobacco, and the Mafia." The Center for Public Integrity, June 2, 2009.

http://www.publicintegrity.org/2009/06/02/2854/montenegro-connection.

SOS Impresa. Le mani della criminalità sulle imprese. Roma: Confesercenti, 2012.

Stoklosa, Michal, and Hana Ross. "Contrasting Academic and Tobacco Industry Estimates of Illicit Cigarette Trade: Evidence from Warsaw, Poland.” Tobacco Control (August 13, 2013): tobaccocontrol-2013-051099. doi:10.1136/tobaccocontrol-2013051099.

The European House Ambrosetti. Studio strategico: I nuovi provvedimenti per il settore del tabacco: i fattori di rischio economici e sociali. Roma: The European House Ambrosetti, 2011. 
Transcrime. Plain Packaging and Illicit Trade in the UK: Study on the Risks of Illicit Trade in Tobacco Products as Unintended Consequences of the Introduction of Plain Packaging in the UK. Milano: Transcrime - Joint Research Centre on Transnational Crime, 2012.

—. Progetto PON Sicurezza 2007-2013: Gli investimenti delle mafie. Rapporto Linea 1. Milano: Ministero dell'Interno, 2013. www.investimentioc.it.

Van Duyne, Petrus C. “Organizing Cigarette Smuggling and Policy Making, Ending up in Smoke." Crime, Law and Social Change 39, no. 3 (2003): 285-317.

Van Duyne, Petrus C., Klaus von Lampe, and Nikos Passas, eds. Upperworld and Underworld in Cross-Border Crime. Nijmegen: Wolf Legal Publishers, 2002.

Van Heuckelom, Carlo. "The Counterfeiting Phenomenon and Its Scale.” presented at the Towards a more effective criminal enforcement of Intellectual Property Rights, Brussels, November 30, 2010.

Von Lampe, Klaus. “Assessing Organized Crime: Provisional Situation Report on Trafficking in Contraband Cigarettes." Trends in Organized Crime 9, no. 2 (December 2005): 8-15.

—. "Explaining the Emergence of the Cigarette Black Market in Germany." In The Organised Crime Economy: Managing Crime Markets in Europe, edited by Petrus C. van Duyne, Klaus Von Lampe, Maarten van Dijck, and James L. Newell. Nijmegen: Wolf Legal Publishers, 2005.

—_. "The Cigarette Black Market in Germany and in the United Kingdom.” Journal of Financial Crime 13, no. 2 (2006): 235-254.

__. "The Illegal Cigarette Trade." In International Crime and Justice, edited by Mangai Natarajan. Cambdirge, UK: Cambridge University Press, 2011. 
—. "The Trafficking in Untaxed Cigarettes in Germany: A Case Study of the

Social Embeddedness of Illegal Markets." In Upperworld and Underworld in Cross-

Border Crime, edited by Petrus C. van Duyne, Klaus von Lampe, and Nikos Passas,

141-161. Nijmegen: Wolf Legal Publishers, 2002.

WHO. "WHO Report on the Global Tobacco Epidemic, 2011, Country Profile Italy," 2011. http://www.who.int/tobacco/surveillance/policy/country_profile/ita.pdf.

Wiltshire, Susan, Angus Bancroft, Amanda Amos, and Odette Parry. "“They're Doing People a Service' Qualitative Study of Smoking, Smuggling, and Social Deprivation.” BMJ 323, no. 7306 (July 28, 2001): 203-207.

Zatonski, Witold. "Democracy and Health: Tobacco Control in Poland." In Tobacco

Control Policy. Strategies, Successes and Setbacks. Washington, D.C.: The World

Bank, 2003.

\footnotetext{
${ }^{1}$ Article 1 FCTC, Use of terms.

"For the purposes of this Convention:
}

(a) "illicit trade" means any practice or conduct prohibited by law and which relates to production, shipment, receipt, possession, distribution, sale or purchase including any practice or conduct intended to facilitate such activity.

$[\ldots]$

(f) "tobacco products" means products entirely or partly made of the leaf tobacco as raw material which are manufactured to be used for smoking, sucking, chewing or snuffing”.

${ }^{2}$ Allen, The Illicit Trade in Tobacco Products and How to Tackle It; von Lampe, "The Illegal Cigarette Trade," 201; Joossens and Raw, "From Cigarette Smuggling to Illicit Tobacco Trade."

${ }^{3}$ Calderoni, Savona, and Solmi, Crime Proofing the Policy Options for the Revision of the Tobacco Products Directive: Proofing the Policy Options Under Consideration for the 
Revision of EU Directive 2001/37/EC Against the Risks of Unintended Criminal Opportunities.

${ }^{4}$ Transcrime, Plain Packaging and Illicit Trade in the UK: Study on the Risks of Illicit Trade in Tobacco Products as Unintended Consequences of the Introduction of Plain Packaging in the UK; The European House Ambrosetti, Studio strategico: I nuovi provvedimenti per il settore del tabacco: $i$ fattori di rischio economici e sociali.

${ }^{5}$ Joossens et al., "Issues in the Smuggling of Tobacco Products."

${ }^{6}$ Nuts is an acronym for Nomenclature des unités territoriales statistiques (Nomenclature of Units for Territorial Statistics). It is the geocode standard for referencing the subdivisions of countries for statistical purposes within the European Union. As of December 2013, there are 270 nuts-2 regions in the EU.

${ }^{7}$ The methodology was developed as part of a research project awarded by the Italian Ministry of Interior to Transcrime (Joint Research Centre on Transnational Crime of Università Cattolica del Sacro Cuore of Milan and Università di Trento) Transcrime, Progetto PON Sicurezza 2007-2013: Gli investimenti delle mafie. Rapporto Linea 1.

${ }^{8}$ Joossens et al., How Eliminating the Global Illicit Cigarette Trade Would Increase Tax Revenue and Save Lives, 13.

9 Joossens et al., "Illicit Cigarettes and Hand-rolled Tobacco in 18 European Countries"; Siggens, Murray, and Walters, West Midlands Regional Illicit Tobacco Survey; NEMS Market Research, North of England Illicit Tobacco Survey.

${ }^{10}$ Ciecierski, "The Market for Legal and Illegal Cigarettes in Poland: A Closer Look at Demand and Supply-Side Characteristics"; Zatonski, "Democracy and Health: Tobacco Control in Poland”; Wiltshire et al., “'They're Doing People a Service’ Qualitative Study of Smoking, Smuggling, and Social Deprivation.”

${ }^{11}$ Joossens and Raw, "Cigarette Smuggling in Europe," 149-150; Levinson, An Inquiry into the Nature, Causes and Impacts of Contraband Cigarettes, 21.

${ }^{12}$ According to experts, for instance, the counterfeiting of cigarettes yields profits equal to forty times the capital invested: van Heuckelom, "The Counterfeiting Phenomenon and Its Scale." and Gutauskas, "Lithuania," 72.. See also van Duyne, "Organizing Cigarette Smuggling and Policy Making, Ending up in Smoke"; von Lampe, "Assessing Organized Crime"; von Lampe, "Explaining the Emergence of the Cigarette Black Market in 
Germany"; Reidy and Walsh, Economics of Tobacco: Modelling the Market for Cigarettes in Ireland.

${ }^{13}$ Ben Lakhdar, Lermienier, and Vaillant, Estimation Des Achats Transfrontaliers de Cigarettes 2004-2007; Merriman, “The Micro-Geography of Tax Avoidance: Evidence from Littered Cigarette Packs in Chicago"; Ben Lakhdar, "Quantitative and Qualitative Estimates of Cross-border Tobacco Shopping and Tobacco Smuggling in France.”

${ }^{14}$ Joossens et al., "Issues in the Smuggling of Tobacco Products," 328.

${ }^{15}$ OCCRP, "Big Trouble at Big Tobacco."

${ }^{16}$ Joossens and Raw, "Cigarette Smuggling in Europe"; Joossens et al., "Issues in the Smuggling of Tobacco Products"; Blecher, "A Mountain or a Molehill”; OCCRP, "Big Trouble at Big Tobacco."

${ }^{17}$ Joossens and Raw, "Cigarette Smuggling in Europe"; Beelman et al., "Tobacco Companies Linked to Criminal Organizations in Lucrative Cigarette Smuggling”; Beelman et al., "Major Tobacco Multinational Implicated In Cigarette Smuggling, Tax Evasion, Documents Show"; Beare, "Organized Corporate Criminality: Corporate Complicity in Tobacco Smuggling"; von Lampe, "The Cigarette Black Market in Germany and in the United Kingdom."

${ }^{18}$ However, in 2011 an investigative report alleged the involvement of Japan Tobacco International in repeated smuggling activities in Middle East. See OCCRP, "Big Trouble at Big Tobacco.”

${ }^{19}$ For instance, since 2004 the four major tobacco companies (Philip Morris International, Japan Tobacco International, British American Tobacco and Imperial Tobacco) have signed agreements with the EU Commission and the Member States aimed at cooperation in the fight against the illicit trade and counterfeiting of tobacco. The agreements stipulate, among other things, the commitment of companies to preventing the illegal tobacco trade with all necessary steps, including the monitoring of exports, which must be proportionate to the demand for tobacco in the destination countries.

${ }^{20}$ Joossens and Raw, "Progress in Combating Cigarette Smuggling."

${ }^{21}$ van Duyne, "Organizing Cigarette Smuggling and Policy Making, Ending up in Smoke”; von Lampe, "The Cigarette Black Market in Germany and in the United Kingdom"; 
Antonopoulos, "Cigarette Smugglers"; Hornsby and Hobbs, "A Zone of Ambiguity: The Political Economy of Cigarette Bootlegging"; von Lampe, "The Illegal Cigarette Trade." ${ }^{22}$ von Lampe, "The Trafficking in Untaxed Cigarettes in Germany: A Case Study of the Social Embeddedness of Illegal Markets."

${ }^{23}$ Coker, "Smoking May Not Only Be Hazardous to Your Health, but Also to World Political Stability"; Seely, Cross Border Shopping and Smuggling.

${ }^{24}$ van Duyne, von Lampe, and Passas, Upperworld and Underworld in Cross-Border Crime.

${ }^{25}$ von Lampe, "Explaining the Emergence of the Cigarette Black Market in Germany."

${ }^{26}$ Kegö, Leijonmarck, and Molcean, Organized Crime and the Financial Crisis Recent Trends in the Baltic Sea Region.

${ }^{27}$ Shelley and Melzer, "The Nexus of Organized Crime and Terrorism: Two Case Studies in Cigarette Smuggling"; Shelley and Picarelli, "Methods Not Motives"; Coker, "Smoking May Not Only Be Hazardous to Your Health, but Also to World Political Stability"; Allen, The Illicit Trade in Tobacco Products and How to Tackle It.

${ }^{28}$ Shen, Antonopoulos, and Von Lampe, “"The Dragon Breathes Smoke"; von Lampe, "The Illegal Cigarette Trade."

${ }^{29}$ Chaloupka and Tauras, The Demand for Cigarettes in Ireland, 19; Niwserwis, Nielegalny Rynek Wyrobów Akcyzowych w Polsce, 6; Gilmore et al., "Towards a Greater Understanding of the Illicit Tobacco Trade in Europe"; Caneppele, Savona, and Aziani, Crime Proofing of the New Tobacco Products Directive; Fooks, Peeters, and Evans-Reeves, "Illicit Trade, Tobacco Industry-funded Studies and Policy Influence in the EU and UK."

${ }^{30}$ Merriman, Yurekli, and Chaloupka, "How Big Is the Worldwide Cigarette-smuggling Problem?," 371-382; Gallus et al., PPACTE, WP2: European Survey on Smoking. Final Report, 20-21.

${ }^{31}$ Merriman, Yurekli, and Chaloupka, "How Big Is the Worldwide Cigarette-smuggling Problem?"; Shafey et al., The Tobacco Atlas. Third Edition.

${ }^{32}$ Euromonitor International, Illicit Trade in Tobacco Products 2012: Will the New Protocol Prove Effective?

${ }^{33}$ Ibid., 23-25.

${ }^{34}$ Blecher, "A Mountain or a Molehill”; Lencucha and Callard, "Lost Revenue Estimates from the Illicit Trade of Cigarettes," 319; Blecher et al., "Euromonitor Data on the Illicit Trade in Cigarettes." 
${ }^{35}$ Joossens et al., How Eliminating the Global Illicit Cigarette Trade Would Increase Tax Revenue and Save Lives, 9-11.

${ }^{36}$ Gallus et al., PPACTE, WP2: European Survey on Smoking. Final Report, 30.

${ }^{37}$ Ibid., 26.

${ }^{38}$ Ibid., 5.

${ }^{39}$ Euromonitor International, "Data on the Penetration of the Illicit Tobacco."

${ }^{40}$ KPMG, Project Star 2012 Results.

${ }^{41}$ The estimation methodology starts from legal domestic sales. The share of legal sales exported is estimated on the basis of empty packs surveys in all Member States. The difference between legal sales and exports provides an estimate of the legal domestic consumption. The consumption of non-domestic cigarettes, also estimated on the basis of empty packs surveys, is added to the legal domestic consumption. The non-domestic consumption is divided between non-domestic legal consumption (estimated on the basis of surveys of consumers' purchases abroad) and contraband \& counterfeiting (the difference between the total non-domestic consumption and domestic non-legal consumption). Ibid., 203 and ff.

${ }^{42}$ Joossens et al., "Illicit Cigarettes and Hand-rolled Tobacco in 18 European Countries"; Gilmore et al., "Towards a Greater Understanding of the Illicit Tobacco Trade in Europe"; Stoklosa and Ross, "Contrasting Academic and Tobacco Industry Estimates of Illicit Cigarette Trade.”

${ }^{43}$ Joossens et al., "Illicit Cigarettes and Hand-rolled Tobacco in 18 European Countries," 5.

${ }^{44}$ Gilmore et al., "Towards a Greater Understanding of the Illicit Tobacco Trade in Europe," 78.

${ }^{45}$ Ibid.

${ }^{46}$ Gallus et al., PPACTE, WP2: European Survey on Smoking. Final Report; Joossens et al., "Illicit Cigarettes and Hand-rolled Tobacco in 18 European Countries."

${ }^{47}$ Stoklosa and Ross, "Contrasting Academic and Tobacco Industry Estimates of Illicit Cigarette Trade"; Chernick and Merriman, "Using Littered Pack Data to Estimate Cigarette Tax Avoidance in NYC"; Merriman, "The Micro-Geography of Tax Avoidance: Evidence 
from Littered Cigarette Packs in Chicago"; Ben Lakhdar, "Quantitative and Qualitative Estimates of Cross-border Tobacco Shopping and Tobacco Smuggling in France.”

${ }^{48}$ Almares, Poland Market Survey: Empty Discarded Pack Collection, August-September 2011; Almares, Poland Market Survey: Empty Discarded Pack Collection, OctoberNovember 2011; Almares, Poland Market Survey: Empty Discarded Pack Collection March - April 2012.

${ }^{49}$ Stoklosa and Ross, "Contrasting Academic and Tobacco Industry Estimates of Illicit Cigarette Trade," 2. The authors grossly misinterpreted the data on the industry-EPSs of 2011. They argued that "despite the original sampling target of 34000 packs, the study collected 694547 discarded cigarette packs [...].The reason this sample size changed so dramatically remains unclear" (ibid.). In fact, the 2011 report by Almares points out that 694,547 are the number of sticks, and not the number of packs (Almares, Poland Market Survey: Empty Discarded Pack Collection, August-September 2011, 7).

${ }^{50}$ Gallus et al., "Price and Consumption of Tobacco in Italy over the Last Three Decades," 334335; Calderoni et al., Italy, 68.

${ }^{51} \mathrm{CPA}$, Relazione sul traffico mafioso di tabacchi e stupefacenti nonché sui rapporti tra mafia e gangsterismo italo-americano (Relatore Zuccalà); Arlacchi, Gli uomini del disonore: La mafia siciliana nella vita del grande pentito Antonino Calderone; Arlacchi, Addio Cosa Nostra; Massari, La Sacra Corona Unita; CPA, Relazione sullo stato della lotta alla criminalità organizzata nella provincia di Brindisi (Rel. Del Turco); CPA, Relazione sul fenomeno criminale del contrabbando di tabacchi lavorati esteri in Italia e in Europa Relatore On. Alfredo Mantovano, 70-74; Paoli, "Mafia and Organised Crime in Italy."

${ }^{52} \mathrm{CPA}$, Relazione sullo stato della lotta alla criminalità organizzata nella provincia di Brindisi (Rel. Del Turco).

${ }^{53} \mathrm{CPA}$, Relazione sul fenomeno criminale del contrabbando di tabacchi lavorati esteri in Italia e in Europa - Relatore On. Alfredo Mantovano, 88.

${ }^{54}$ DIA, Esito Attività Di Indagine Svolta Sul Conto Di Djukanovic Milo + 4. N. 125/BA/2 ${ }^{\circ} \mathrm{SN}$. 125/BA/2 ${ }^{\circ}$ Sett. Inv. Giud. /H5. 148-1/ 1379 Di Prot.ett. Inv. Giud. /H5. 148-1/ 1379 Di Prot., 
14; Ivanovic, "Speedboats, Cigarettes, Mafia and Montenegrin Democracy"; Sisti, "The Montenegro Connection: Love, Tobacco, and the Mafia."

${ }^{55}$ Ivanovic, "Speedboats, Cigarettes, Mafia and Montenegrin Democracy."

${ }^{56}$ Ibid.

${ }^{57}$ Sisti, "The Montenegro Connection: Love, Tobacco, and the Mafia."

${ }^{58}$ Ibid.

${ }^{59} \mathrm{CPA}$, Relazione sul fenomeno criminale del contrabbando di tabacchi lavorati esteri in Italia e in Europa - Relatore On. Alfredo Mantovano, 80-88; Calderoni et al., Italy. The Factbook on the Illicit Trade in Tobacco Products 2., 69.

${ }^{60} \mathrm{CPA}$, Relazione sul fenomeno criminale del contrabbando di tabacchi lavorati esteri in Italia e in Europa - Relatore On. Alfredo Mantovano, 89-91.

${ }^{61}$ Ibid., 88-96.

${ }^{62}$ Ibid., 41.

${ }^{63}$ Joossens and Raw, "Progress in Combating Cigarette Smuggling”; DNA, Relazione annuale 2006, 284.

${ }^{64}$ DNA, Relazione annuale sulle attività svolte dal Procuratore nazionale antimafia e dalla Direzione nazionale antimafia nonché sulle dinamiche e strategie della criminalità organizata di tipo mafioso nel periodo $1^{\circ}$ luglio 2011 - 30 giugno 2012, 377-383; Russo, Interview with Giovanni Russo, Direzione Nazionale Antimafia; Di Lucia, Interview with Massimiliano Di Lucia, Guardia di Finanza.

${ }^{65}$ SOS Impresa, Le mani della criminalità sulle imprese.

${ }^{66}$ Gallus et al., "Cigarette Smuggling in Italy, 2005-8”; Gallus et al., PPACTE, WP2: European Survey on Smoking. Final Report.

${ }^{67}$ Gallus et al., PPACTE, WP2: European Survey on Smoking. Final Report, 67.

${ }^{68}$ Nomisma, La contraffazione delle sigarette in Italia primo rapporto nomisma.

${ }^{69}$ Ibid., 80.

${ }^{70}$ Correspondence with the authors of the Nomisma estimates revealed that these were calculated using an "econometric model" based on seizures and on the possibility to check incoming loads and those circulating in the area (e-mail from Silvia Zucconi, 31 May

2012, h. 13:34). 
${ }^{71}$ KPMG, Project Star 2012 Results, 118.

${ }^{72}$ Euromonitor International, "Data on the Penetration of the Illicit Tobacco."

${ }^{73}$ Joossens et al., "Illicit Cigarettes and Hand-rolled Tobacco in 18 European Countries"; Gilmore et al., "Towards a Greater Understanding of the Illicit Tobacco Trade in Europe"; Stoklosa and Ross, "Contrasting Academic and Tobacco Industry Estimates of Illicit Cigarette Trade.”

${ }^{74}$ Data available from the data warehouse of the Italian National Institute of Statistics, entry Services and Tourism, ISTAT, "I.Stat: Movimento dei clienti negli esercizi ricettivi - dati annuali nazionali, ripartizionali e provinciali."

${ }^{75}$ Formisano and Vico, Commissione parlamentare d'inchiesta sui fenomeni della contraffazione e della pirateria in campo commerciale-Relazione sulla contraffazione nel settore del tabacco.

${ }^{76}$ KPMG, Project Star 2012 Results; EPSs data were provided in the context of the project the Factbook on the Illicit Trade in Tobacco products, conducted by Transcrime with the financial contribution of PMI. See Calderoni et al., Italy.

${ }^{77}$ Remarkably, in some countries HRT shows high levels of illicit products and this suggest that future estimates should include it (See e.g. Calderoni et al., United Kingdom).

${ }^{78}$ KPMG, Project Star 2012 Results.

${ }^{79}$ Gilmore et al., "Towards a Greater Understanding of the Illicit Tobacco Trade in Europe.”

${ }^{80}$ Within every area, two collection routes are defined: one within a $250 \mathrm{~m}$ radius and one within a 500m radius from the center. Collectors are unaware of the total number of packs to be collected in the area and therefore they walk through the whole first route. Subsequently, a supervisor checks the number of packs collected; if the number is less than thirty, a second collection through the second route is conducted. If the number is still insufficient, the collection starts again from the first route. If more than thirty packs are collected, the supervisor randomly removes packs. The packs are collected either from the streets or from the top of trash bins, without rummaging. 
${ }^{81}$ Joossens et al., "Illicit Cigarettes and Hand-rolled Tobacco in 18 European Countries";

Gilmore et al., "Towards a Greater Understanding of the Illicit Tobacco Trade in Europe";

Stoklosa and Ross, "Contrasting Academic and Tobacco Industry Estimates of Illicit

Cigarette Trade."

${ }^{82}$ Ben Lakhdar, "Quantitative and Qualitative Estimates of Cross-border Tobacco Shopping and Tobacco Smuggling in France,” 16.

${ }^{83}$ Merriman, "The Micro-Geography of Tax Avoidance: Evidence from Littered Cigarette Packs in Chicago"; Chernick and Merriman, "Using Littered Pack Data to Estimate Cigarette Tax Avoidance in NYC"; Stoklosa and Ross, "Contrasting Academic and Tobacco Industry Estimates of Illicit Cigarette Trade.”

${ }^{84}$ Gilmore et al., "Towards a Greater Understanding of the Illicit Tobacco Trade in Europe."

${ }^{85}$ Ibid., 3.

${ }^{86}$ Chernick and Merriman, "Using Littered Pack Data to Estimate Cigarette Tax Avoidance in NYC," 641; ibid., 81.

${ }^{87}$ Fooks, Peeters, and Evans-Reeves, "Illicit Trade, Tobacco Industry-funded Studies and Policy Influence in the EU and UK"; Stoklosa and Ross, "Contrasting Academic and Tobacco Industry Estimates of Illicit Cigarette Trade.”

${ }^{88}$ The surveys did not include any city from the three smallest regions (Basilicata, Molise and Valle d'Aosta) and Sardinia. The missing values were imputed by calculating the average of the regional shares of neighbouring regions (for Sardinia, an island, the national value was used). In 2012, the EPS for the city of Naples were outliers, due to exceptionally high shares of non-domestic packs (46\% and 50\% for Q2 and Q4 respectively). To prevent bias in the estimates, the regional share for Naples's region, Campania, was reduced to the level of the second highest region (North-Eastern Friuli-Venezia-Giulia), passing from $39.9 \%$ to $23.7 \%$. Moreover, Campania was not included in the neighboring regions for the purpose of imputing missing values in 2012.

${ }^{89}$ This passage was due to the fact that the adjustment for the illicit consumption was done using percentage variables. These could not take into account the differences among the regions in terms of absolute values. This would have resulted in the sum of the regional 
illicit markets being different from the estimate by KPMG, which would have contrasted with the assumption of Project Star's results as the starting point of the estimation.

${ }^{90}$ KPMG, Project Star 2010 Results; KPMG, Project Star 2012 Results; WHO, "WHO Report on the Global Tobacco Epidemic, 2011, Country Profile Italy."

${ }^{91}$ Joossens et al., How Eliminating the Global Illicit Cigarette Trade Would Increase Tax Revenue and Save Lives, 15.

92 The illicit market volumes were converted into equivalent legal market values. The calculation considered the average price of the most popular price category for 2009-10 and the weighted average price of all consumed cigarettes for 2011-12. The total tax as a share of the mentioned price was applied to the legal market values (taxes remained relatively constant at approximately $75 \%$ of the final retail prices in the period). Data on prices and taxes are at July of each year (See European Commission, "Manufactured Tobacco: Excise Duty Rates - European Commission"). The figures may actually underestimate the tax evasion due to the ITTP, since the calculations for 2009 and 2010 are based on the most popular price category, which is generally cheap products, while those for 2011 and 2012 are based the actual composition of legal sales in Italy. Both approaches are based on pack prices, which may be lower than the products trafficked most often (frequently medium and premium brands). If based on Marlboro prices, estimated total tax loss from 2009 to 2012 would have reached $€ 3.4 \mathrm{bn}$ ( $+16 \%$ compared to the figures in the text).

${ }^{93}$ The European House Ambrosetti, Studio strategico: I nuovi provvedimenti per il settore del tabacco: i fattori di rischio economici e sociali, 34 . For a more accurate measurement of the tax losses caused by the ITTP, it should be considered that in theory the removal of illicit cigarettes would result in a general increase of the market price and, in turn, to a reduction of consumption.

${ }^{94}$ Regional IMadj volumes were divided by 20 and by $\mathrm{Sm}$.

${ }^{95}$ In July 2012, the cheapest brand price was $€ 2.8$ in Slovenia and $4.3 €$ in Italy. See Calderoni et al., Italy, 75 and 85.

${ }^{96}$ Paoli, "The Paradoxes of Organized Crime."

${ }^{97}$ Transcrime, Progetto PON Sicurezza 2007-2013: Gli investimenti delle mafie. Rapporto Linea 1 .

${ }^{98}$ SOS Impresa, Le mani della criminalità sulle imprese. 